\title{
DE NUEVO, SOBRE EL SUSTRATO PÚNICO EN EL MUNDO FUNERARIO DE LA BÉTICA. REFLEXIONES, DESDE LA INCERTIDUMBRE*
}

\author{
AGAIN, ON THE PUNIC SUBSTRATE OF THE BAETICA FUNERARY \\ WORLD. REFLECTIONS FROM UNCERTAINTY
}

\author{
DESIDERIO VAQUERIZO GIL**
}

\begin{abstract}
Resumen: En algunas de las necrópolis urbanas hispano-béticas más significativas se detecta un sustrato púnico que habría matizado (y se habría visto matizado por ella) a la población prerromana con la que convivió, hasta casi confundirse en realidad única y mestiza, lo que hace particularmente difícil (cuando no imposible) su individualización respectiva. Con esta aportación, el autor vuelve a poner sobre el tapete de la discusión científica algunas reflexiones, preguntas y propuestas personales de investigación que le ocupan en los últimos años, actualizando con ello un tema que, no obstante, queda completamente abierto.
\end{abstract}

Palabras clave: Necrópolis romanas, Baetica, Monumentalización funeraria, Cupae, Etnicidad, Hibridismo.

\section{EN HOMENAJE A MANUEL BENDALA}

Vuelvo en este trabajo, de forma breve, sobre argumentos que he tratado con mayor exhaustividad no hace mucho (Vaquerizo 2006 y 2010a), animado por el único objetivo de rendir homenaje con un tema muy

\footnotetext{
* Gracias a Eduardo Ferrer por invitarme a participar en un homenaje que en principio estaba reservado a las colegas de la Universidad Hispalense, permitiéndome con ello dejar constancia pública de la admiración y el profundo afecto que siento desde mi época de estudiante por M. Bendala. Ya entonces me dispensó un trato amigable y cercano, demostrando una vez más (porque no fui, ni he sido el único) que los verdaderamente grandes no necesitan aparentarlo ni rodearse de escenografía o corte alguna.

$\mathrm{Mi}$ agradecimiento también a aquellas personas o instituciones que me han facilitado el trabajo, ayudándome con la búsqueda
}

\begin{abstract}
In some of the most significant Hispano-Betic urban necropolis it can be detected a Punic substratum that would have tinged the pre-roman population coexistent -and would have been tinged by it as well-, until they both would have merged into an only and mixed reality. This makes particularly difficult, when not impossible, their individuali-zation. With this contribution the author places again into the scene of scientific discussion some personal reflections, questions and suggestions for research in which he has been working in the last few years. With this he helps to update a topic that is still wide opened.
\end{abstract}

Key words: Roman necropolis, Baetica, Funerary monumentalization, Cupae, Ethnicity, Hybridity

querido para él a uno de los arqueólogos españoles más sólidos y carismáticos de nuestra historia reciente: Manuel Bendala Galán; importante no sólo por su producción y la escuela que deja, sino también por su talla personal extraordinaria, un caballero en la acepción más noble y clásica de la palabra, que ha sabido derrochar ciencia y bonhomía a partes iguales, dejando un poso imperecedero en todos los que en algún momento

bibliográfica o el material fotográfico. Entre ellas quiero destacar especialmente al Conjunto Arqueológico de la necrópolis de Carmona, en la persona de su director, Ignacio Rodríguez Temiño, y a Verónica Gómez Fernández, de Cádiz.

** Catedrático de Arqueología. Universidad de Córdoba. Investigador Principal del Grupo de Investigación Sísifo (HUM-236, del Plan Andaluz de Investigación). 
de su dilatada y fructífera trayectoria hemos contado con el privilegio de su amistad y de su ejemplo.

Su jubilación demasiado temprana es sólo un síntoma añadido de sus enormes agudeza y alcance, al reservar, inteligentemente, su etapa de mayor madurez para hacer algo más que Arqueología (consciente de los mil y un santos Griales que ofrece la existencia), pero también deja encueros y con las vergüenzas al aire la profunda crisis conceptual, de estructura y de valores que atraviesa la Universidad española (por no hablar de la sociedad, o la incertidumbre de un futuro muy poco halagüeño), incapaz de retener en sus filas a los mejores, más brillantes y comprometidos de entre sus docentes e investigadores, asfixiándolos con tareas ajenas por completo a su preparación y capacidad intelectual hasta provocar que huyan despavoridos. Algo sobre lo que sería necesaria una reflexión profunda y urgente con el fin de diagnosticar las razones del mal para, a continuación y en consecuencia, poner fin de forma expeditiva y contundente a la metástasis, recuperando así, en la medida de lo que aún sea posible, la universitas perdida, el sentido del decoro y de responsabilidad compartida.

La institución se queda, pues, sin uno de sus primeros espadas, pero no así sus amigos, colegas y discípulos (tampoco la ciencia) que, me consta, seguiremos contando con él como si continuara en activo (porque así seguirá, sin duda, a efectos de producción y agenda); y es que la persona, en este caso, le ha ganado siempre la partida al arqueólogo, afortunadamente para todos. En esta ocasión se impone la vida, que lo reclama para ella consciente de haber sido marginada con demasiada frecuencia. Por eso, Manolo, déjame que me congratule públicamente de tu decisión y que, apelando quizás de manera un poco recurrente a la semántica estricta de la palabra, exprese mi alborozo sincero ante tu retirada, que no es tal, sino victoria. Disfruta y no mires atrás, porque muchos te seguiríamos si pudiéramos, aquejados de esa misma pérdida de fe que hace tan difícil mantenerse con un mínimo de entusiasmo en la brecha; sabedores, en el fondo, de que con la jubilación no termina nada: antes al contrario, comienza.

\section{SOBRE LA TRADICIÓN PÚNICA, O LOS INFLUJOS NORTEAFRICANOS, EN EL MUNDO FUNERARIO DE LA BÉTICA ${ }^{1}$}

Éste fue el título de uno de mis trabajos (Vaquerizo 2006), en el que, por primera vez, abordé el tema de

1. Este trabajo fue entregado a imprenta a principios de 2011. Desde entonces, hasta su última corrección, es mucha la bibliografía forma específica. Años después volvería sobre él al tratar las más significativas necrópolis urbanas de la Bética (Vaquerizo 2010a), en algunas de las cuales se detecta un sustrato púnico -entendiendo dicho etnónimo en su valor cultural, pero también étnico- que, en cualquier caso, habría matizado (y se habría visto matizado por ella) a la población prerromana con la que convivió, hasta casi confundirse en realidad única y mestiza ${ }^{2}$, lo que hace particularmente difícil (cuando no imposible) su individualización respectiva ${ }^{3}$. Así ocurre en conjuntos urbanos como los de Baelo Claudia, Carissa Aurelia, Onuba, Carmo, Corduba, Hispalis o Malaca, varios de los cuales contaron con cecas que acuñaron moneda con metrología, iconografía e incluso alfabeto púnico-turdetano (García-Bellido y Blázquez 2001)4. Tal circunstancia parece no dejar duda alguna en cuanto al matiz etnográfico de su población (o cuando menos de parte de ella).

Las novedades, pues, desde mi último trabajo de conjunto no son muchas, con excepción quizás de $G a$ des, cuyas necrópolis comienzan a ser objeto de atención preferente (Arévalo 2009; Vaquerizo 2010b; Niveau 2010; Niveau y Gómez 2010 a y b) ${ }^{5}$, convirtiéndose por derecho propio en las de mayor potencial de cara a un futuro no demasiado lejano, toda vez que las del caput Baetica han sido ya bien caracterizadas (Vaquerizo 2008 y 2010a, 105 ss.; Ruiz Osuna 2010, también las tres con abundante bibliografía anterior).

sobre el mundo funerario hispanorromano que ha visto la luz, entre ella estudios de enorme interés para el tema que aquí me ocupa sobre Hispalis, Baelo Claudia, Carmona (vid. el trabajo contenido en este mismo volumen) o aspectos concretos del ritual o determinadas expresiones sepulcrales como las cupae. Téngase en cuenta a la hora de valorar sus carencias, y también las ausencias.

2. Pasando de "menestra" a "crema de verduras" (con todos los matices de integración que ello implica), en afortunada metáfora de M. Bendala (2006a).

3. Los cartagineses, su papel político y cultural en el Mediterráneo de la segunda mitad del I milenio a.C., y más en concreto la intensidad de su acción militar y colonizadora en el sur de la Península Ibérica (también, las poblaciones de origen colonial previo y su un tanto etérea -por la indefinición de las fuentes, textuales y arqueológicas- realidad cultural, política e incluso cívica), están siendo objeto de atención especial por parte de la comunidad científica estos últimos años (vid. por ejemplo Ferrer y Álvarez 2009, con bibliografía anterior). Sobre el hibridismo de las comunidades indígenas y después de éstas con Roma, destacan los trabajos de Alicia Jiménez Díez $(2005,2006$ y 2008) y también del propio Bendala (2006, a y b, por sólo citar algunos de los más recientes)

4. Expresando así "el interés de las entidades emisoras en dejar constancia de su idiosincrasia, de un factor económico concreto y/o de su adhesión a una determinada política" (Ferrer 2006: 270).

5. Todas estas obras incluyen multitud de referencias a trabajos anteriores, y la última de ellas, además, varios artículos monográficos sobre el tema 
Así las cosas, no pretendo otra cosa con esta aportación que volver a poner sobre el tapete de la discusión científica algunas reflexiones, preguntas y propuestas personales de investigación sobre las que, obviamente, poco más puedo aportar. Será necesario seguir trabajando duro para llegar algún día a nuevas conclusiones.

\section{LA REALIDAD ARQUEOLÓGICA}

El tan discutido (y evanescente, por lo que se refiere a su identificación material) sustrato púnico en el mundo funerario hispano-bético viene siendo rastreado arqueológicamente en numerosos aspectos de los que yo ahora sólo recordaré aquéllos a cuya resolución, o por lo menos correcta definición, ha contribuido de manera determinante el homenajeado:

\section{a) Topografía y monumentos funerarios}

Está bien comprobado que algunas ciudades béticas perpetúan en época romana los mismos espacios funerarios utilizados durante su etapa púnica ${ }^{6}$, lo que dio lugar a frecuentes superposiciones. Es el caso, por ejemplo, de Gades, Onuba (Vaquerizo 2010a, 269 ss.) y también Malaca, en zonas, esta última, como la ladera meridional del monte Gibralfaro, donde inhumación $(57 \%)^{7}$ y cremación $(43 \%)^{8}$ alternan de forma similar

6. No ocurre así en otras, caso de Hispalis, donde, a pesar de su pasado prerromano de filiación púnica, no he podido localizar manifestación material alguna que permita suponer para ella un sesgo cultural no normativo (entendiendo por tal lo romano en sentido estricto); algo que, dada su posición geoestratégica y entidad económica y cultural, así como su cercanía a otros centros urbanos en los que esa presencia viene siendo reivindicada desde antiguo y parece cada vez más clara, no deja de ser sorprendente (estas afirmaciones quedan matizadas tras la publicación de la obra de Daniel González Acuña "Forma Vrbis Hispalensis". El urbanismo de la ciudad romana de "Hispalis" a través de los testimonios arqueológicos, Sevilla, 2011, a cuya consulta ineludible remito).

7. Los inhumados se disponen en decúbito lateral derecho y orientación Oeste-Este, con el rostro mirando hacia el Sur, al igual que los de la fase más antigua (casos similares y con la misma cronología se documentan también en las necrópolis de Cádiz; Cobos 1999: 24 ss.). Sólo una de las tumbas ha conservado la señalización externa: una estela cerámica de forma pentagonal elaborada a partir de un ladrillo (Martín Ruiz, Pérez-Malumbres 2001: 307 ss.).

8. Todas ellas secundarias. No se han detectado ustrina. Por otra parte, en las urnas sólo se recogieron los restos óseos, nunca las cenizas. Una de las ollae contenía además restos de fauna, que dejan entrever la práctica más que posible de banquetes funerarios. También incorporaron en su mayor parte algo de ajuar, aunque la información al respecto es bastante limitada. Sí se señala expresamente la escasez a otras necrópolis púnicas contemporáneas (caso de Villaricos; Almagro Gorbea 1984; Rodero et alii 1996), o el suburbium septentrional de la ciudad, donde en el entorno de las calles Franquelo/Beatas ha sido localizado otro importante espacio funerario de época tardorrepublicana, con ajuares típicos de la época -a caballo entre la tradición púnica y los nuevos usos típicos de época hispanorromana, testimonio claro de los primeros tiempos de mixtificación- que incorporan cerámicas campanienses y ungüentarios fusiformes de tradición helenística (Corrales y Mora 2005: 126 ss., fig. 99).

\section{Gades}

Que en las necrópolis gaditanas de los primeros siglos de presencia romana se diera una fuerte impronta púnica (más que propiamente itálica), es algo lógico y con amplia justificación histórica, supuesto el protagonismo de la ciudad en el contexto del Extremo Occidente (Ferrer 2006), el origen remoto de su población, sus relaciones directas con Cartago y la larga perduración de sus señas de identidad prerromanas (Muñoz Vicente 2008; Guzmán 2008, 85 ss.; Ferrer 2010)9 ${ }^{9}$. Esto no evita que en algunos sectores se observe un cambio claro entre las últimas tumbas fenopúnicas o púnicoromanas, realizadas conforme al rito de la inhumación, y las propiamente republicanas, que en ocasiones usan de la cremación como rito único ${ }^{10}$. Así ocurre en las excavaciones practicadas en los Cuarteles de Varela (Miranda et alii 2001-2002: 255 ss.), aunque lo normal es comprobar cierta continuidad (y, por consiguiente, un claro hibridismo, conducente en último término a la aceptación plena del ritual romano), que a veces hace complicado incluso reconocer la filiación cultural de algunos enterramientos (Morales 2006: 39).

de materiales de origen itálico, lo que parece reflejar una cierta autonomía cultural y religiosa (y por ende funeraria) de la comunidad púnica malacitana frente al invasor durante un periodo largo de tiempo, como ha sido destacado también en otras necrópolis, caso nuevamente de Cádiz (Martín Ruiz y Pérez-Malumbres 2001: 309 ss.) u Onuba (Vaquerizo 2010a: 276), en un rasgo aparentemente normativo que, sin embargo, empieza a mostrar algunas fisuras (vid. infra), por lo que quizás deba ser revisado.

9. Vid. también los numerosos trabajos al respecto de A.M $\mathrm{M}^{\mathrm{a}} \mathrm{Ni}-$ veau de Villedary, recogidos en Niveau (2010) y Niveau y Gómez (2010 a y b).

10. La tradición historiográfica ha supuesto siempre para Cádiz un predominio absoluto de la inhumación hasta los siglos pleno-imperiales. Sin embargo, la arqueología ha demostrado estos últimos años que inhumación y cremación coexisten desde época republicana, y que la segunda se sirve de ollae ossuariae de tradición púnica aún en el siglo I d.C. (López Rosendo 2010). 


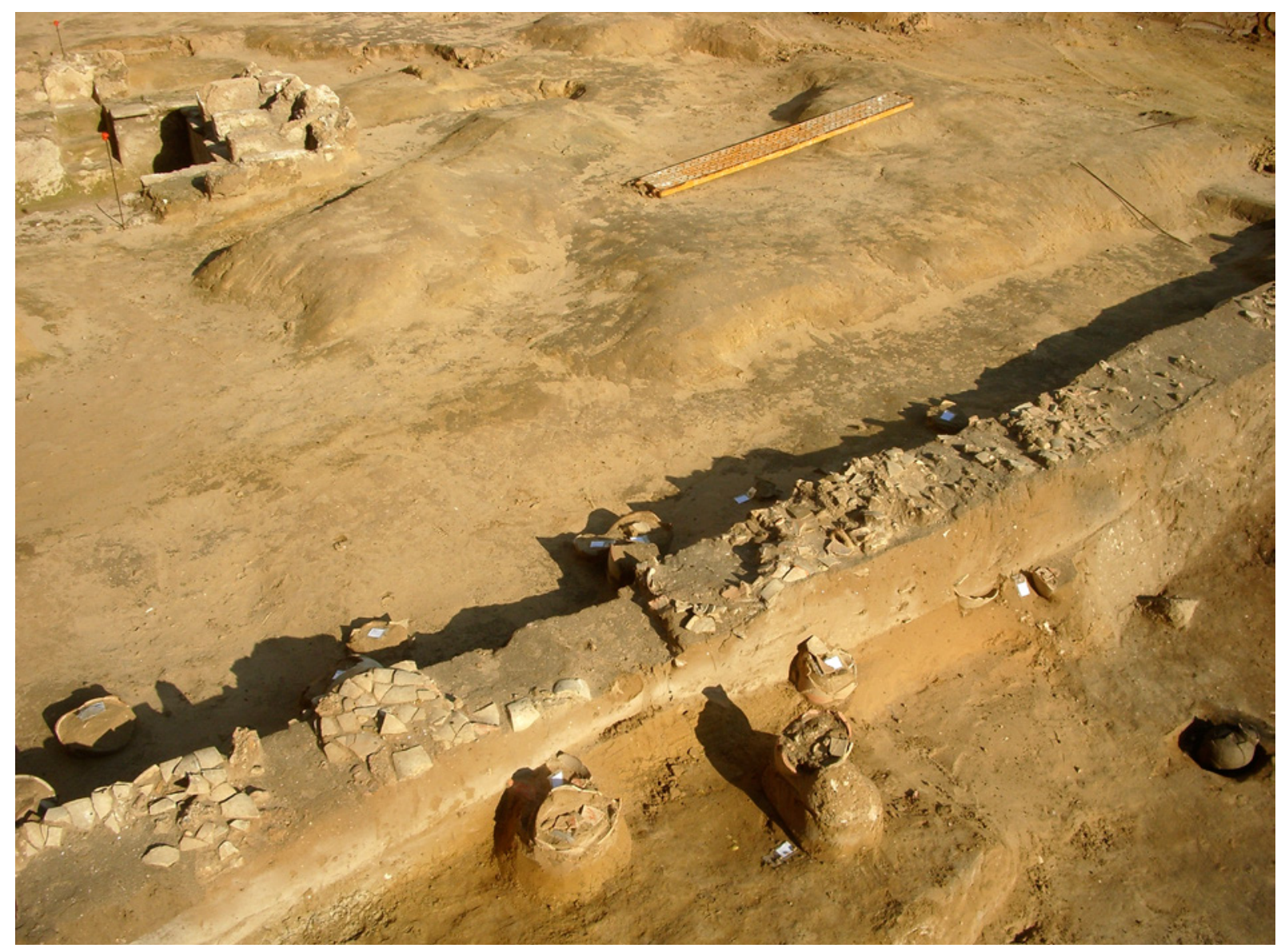

Figura 1. Ciudad de la Justicia, Cádiz. Muro delimitado por ánforas (Fotog. V. Gómez y F. J. Sibón).

Entre otros muchos ejemplos de continuidad ritual y tipológica destacan las trece inhumaciones excavadas bajo el Teatro Andalucía, una zona supuestamente intramuros, con toda la problemática que ello implica. Algunos de los enterramientos, en decúbito supino, decúbito lateral izquierdo y decúbito lateral derecho, además de varias posturas un tanto forzadas y poco frecuentes en varios de los cadáveres (Macías 2009; Vaquerizo 2010a: 279 ss.), presentan particularidades que recuerdan otras bien documentadas en necrópolis de época fenicia $u$ orientalizante como La Joya, en Huelva, Cruz del Negro y El Acebuchal, en Carmona, o La Angorrilla, en Alcalá del Río (Sevilla) (Fernández Flores y Rodríguez 2007, con bibliografía actualizada), lo que podría estar avalando aquella continuidad cultural a la que antes aludía.

Cuento también con referencias a recintos y acotados funerarios delimitados por alineaciones de piedras "betiloides" y ánforas clavadas en la arena, que sirvieron para señalizar enterramientos y a la manera de cipos terminales, en puntos muy diversos de la ciudad: Naves de
Abarzuza, calle Brunete, calle Cruz Roja, calle Huerta del Obispo, calle Gas, Ciudad de la Justicia, Cuarteles de Varela, etc. (Miranda et alii 2001-2002: 264 ss.; Gómez Fernández 2007: 81; Niveau 2010) (Figura 1). A este sistema, que parece hundir sus raíces en época tardopúnica (siglo III a.C.) y refleja una cierta planificación del espacio funerario, se suman en ocasiones cimientos de mampostería, cisternas, piletas, pozos y fosas rituales en los que se depositaban los restos de banquetes y celebraciones en homenaje y recuerdo de los familiares desaparecidos (Miranda et alii 2001-2002, en particular 258 ss.; Niveau 2010) vid. infra-, conformando todo ello un paisaje funerario lejos aún de ofrecernos su imagen completa pero que poco a poco empieza a mostrar sus muchas singularidades.

Con todo, los tipos de señalización funeraria más habituales en las necrópolis gaditanas debieron ser el cipo y la estela (Figura 2, A y B), ambos en piedra ostionera estucada y con un rebaje en su parte superior para el $t i$ tulus sepulcralis, grabado sobre una placa de mármol después encastrada en el soporte de piedra (López de la 


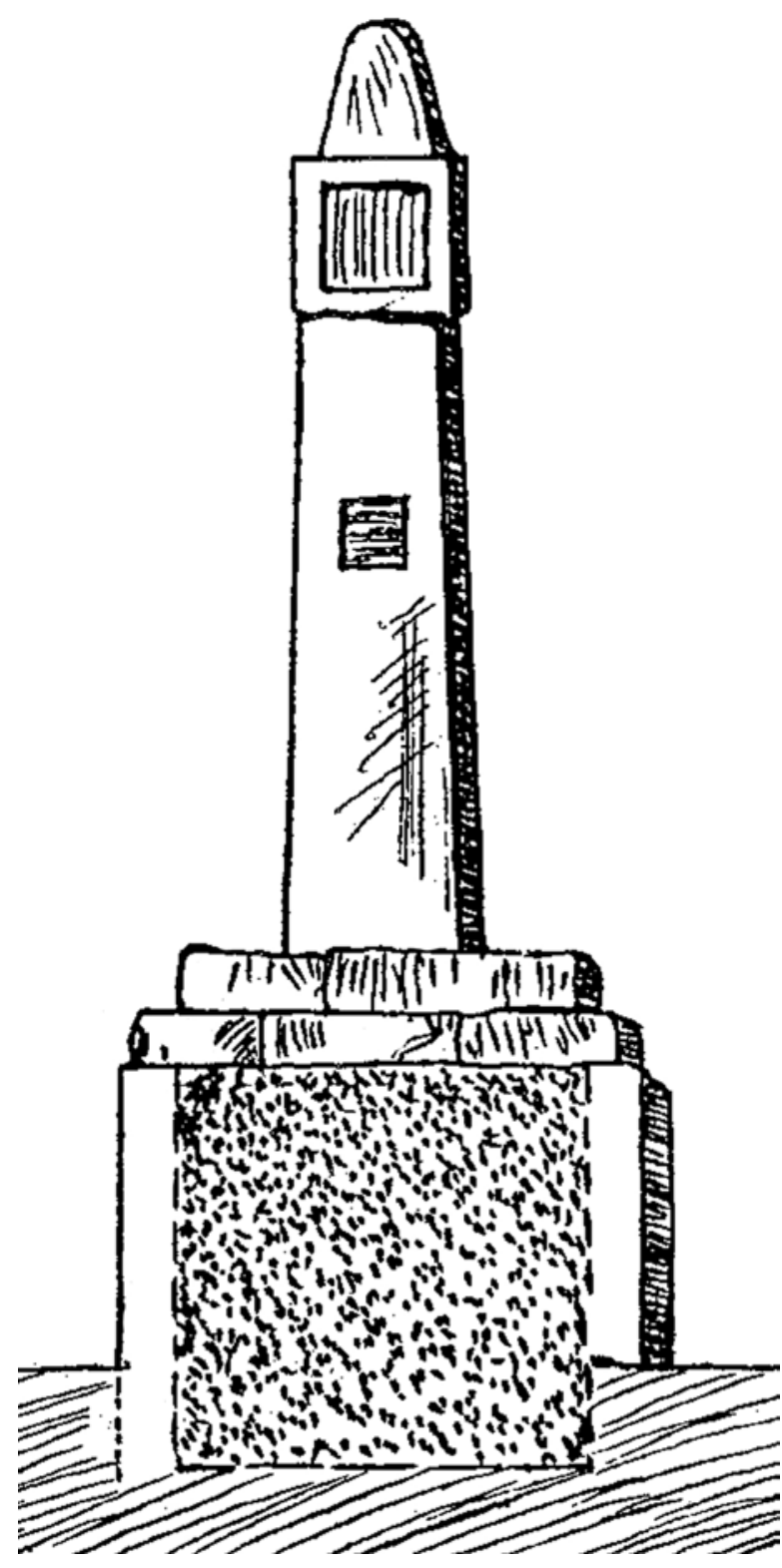

Orden 1997: 256). Se conocen infinidad de ejemplos, aunque sólo raramente disponemos de un mínimo de información sobre el contexto arqueológico en que aparecieron (Vaquerizo 2010a: 157 ss.; 2010b: 363 ss.). Las estelas fueron un tipo de señalización funeraria muy habitual en el Mediterráneo antiguo, particularmente en ámbito púnico. Sin embargo, salvo en un caso, en las gaditanas falta siempre el símbolo habitual de Tanit, que podría haberse mantenido sin dificultad en época romana (Corzo 1992: 276); como de hecho lo hizo en otros lugares y sobre otros soportes - vid. infra-.

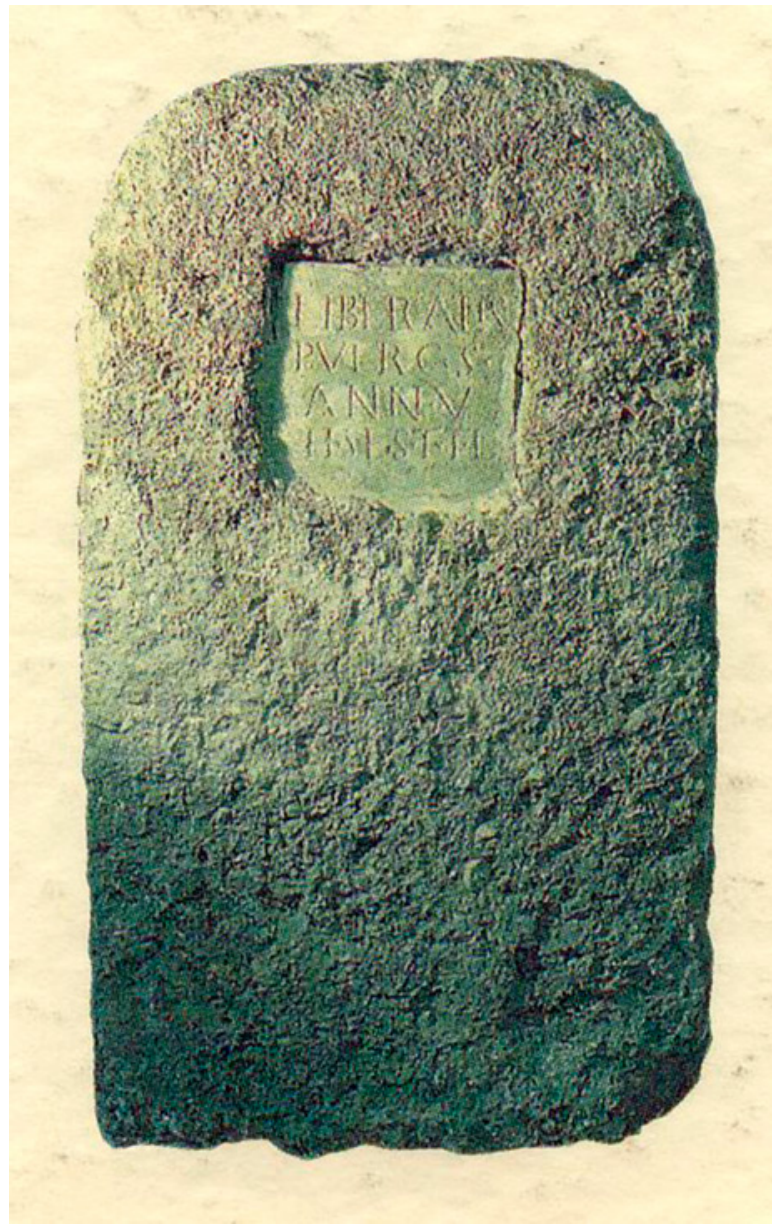

Figura 2. A) Necrópolis de Cádiz. Estela funeraria de Lucrecia Pannyghis (Quintero Atauri 1932, 26) B) Cipo funerario con titulus sepulcralis en placa marmórea encajada en su parte superior (López de la Orden, Ruiz 1995, Portada, nº 293).

\section{Carmo}

Sin duda, la necrópolis bética que más ha dado de sí desde el punto de vista que ahora nos interesa ha sido la occidental de Carmona (Bendala 1976) ${ }^{11}$, ejemplo

11. La importancia estratégica del asentamiento; su papel determinante en la historia de la región desde la llegada de los primeros fenicios al interior de Tartessos, o la impronta púnica que parece mantener su población hasta tiempos plenamente romanos, derivada básicamente del protagonismo político y militar que ejerce la ciudad durante la época de los Barca, han sido más que destacados por 
claro de "etnicidad activa" en opinión precisamente de M. Bendala (2002b: 142), contestada sólo por una mínima parte de la comunidad científica, que en estos últimos años viene cuestionando la interpretación tradicional del conjunto (Fear 1990; Alföldy 2001: 384). El sepulcretum, de monumentalidad bien documentada gracias, en buena medida, al carácter hipogeico de muchos de sus enterramientos, arranca en realidad desde la Puerta de Sevilla, por donde la vía Augusta abandonaba la ciudad en dirección a Hispalis, combinando en todo momento los usos funerarios con otros residenciales, industriales, públicos (caso de la fuente del Paseo del Estatuto) (Gómez Saucedo 2001: 882; Anglada y Conlin 2001: a y b) y, por supuesto, ideológicos.

Un equipo dirigido por M. Belén excavó en la zona del anfiteatro algunos enterramientos en urnas cerámicas de tradición indígena (¿quizá púnica?; Belén 1982) $)^{12}$, y una decena de cremaciones bajo bóvedas y estructuras piramidales de ladrillo (Belén et alii 1986: 56-57, fig. 4), similares a otros casos conocidos en la misma localidad desde antiguo (Paris et alii 1926: 69). A ellos se ha sumado algún bustum más bajo bóveda latericia (Cardenete et alii 1991: 577, Incineración I, lám. II), y varias inhumaciones de cronología no bien aclarada (Cardenete et alii 1991: 579 ss., lám. III; Anglada y Conlin 2003a), que tal vez tienen que ver con la ocupación tardía de la zona, prolongada cuando menos hasta el siglo VII (Anglada y Conlin 2001a).

Se trata, pues, de un sector funerario bastante denso, en uso durante casi mil años, lo que da idea de su complejidad. Un paisaje en el que las tumbas familiares con cámaras hipogeicas serían las preferidas únicamente entre los años iniciales del Imperio y comienzos del siglo II, cuando se empiezan a imponer otras modalidades (Belén 1983; Belén et alii 1986; Belén, Lineros y Puya 1987). A ellas, excavadas en la roca, estucadas, pintadas y selladas con frecuencia mediante

la literatura al uso (vid. por ejemplo al efecto Bendala 1976; 1981 38 ss., o 1982: 197 ss.; Belén et alii 1997 o Caballos, 2001, última obra de conjunto en la que se recogen varios trabajos de interés al respecto).

12. En opinión de J.L. Escacena, la necrópolis occidental carmonense correspondería a sus habitantes de tradición púnica y a los primeros romanos, pero no así a la etnia de base turdetana, que mantendría hasta el triunfo definitivo de la inhumación sus rituales típicos de la Protohistoria, no detectables desde el punto de vista arqueológico (Escacena 2001: 33). A mi juicio, sin embargo, conviene huir de las categorizaciones, por cuanto el hibridismo es una corriente de ida y vuelta que afecta a todas las partes interactuantes. La información de que disponemos es tan limitada que resulta difícil pronunciarse sobre la etnicidad de tales enterramientos; en particular, cuando no conservamos documentos epigráficos clarificadores.

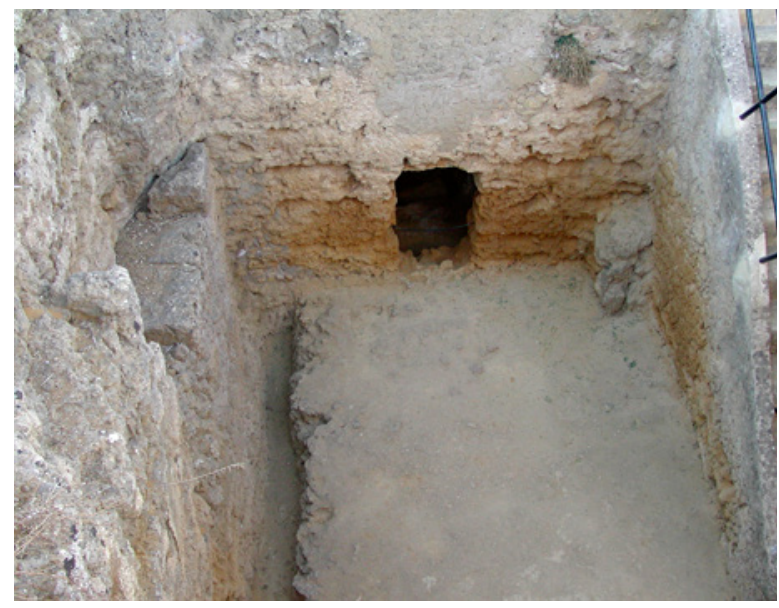

Figura 3. Necrópolis occidental de Carmona. Tumba de Postumio (Fotog. Conjunto Arqueológico de la Necrópolis Romana).

grandes losas o bloques de piedra que podían desplazarse con facilidad para permitir la deposición de nuevos enterramientos, se accede a través de un pozo más o menos desarrollado, que se cegaba de manera definitiva en el momento de clausurar el sepulcro. También, mediante una escalera; sobre todo, cuando dicho pozo fue ampliado hasta convertirse en un patio anejo a la cripta, en el que se disponía la pira funeraria y, a veces, algunos enterramientos ${ }^{13}$. Destacan a este respecto la tumbas de Postumio y de Prepusa (Figuras 3 y 4). No obstante, lo normal fue que las cremaciones se realizaran en ustrina de carácter familiar o comunitario; cuando no en simples busta en los que el cadáver era quemado y enterrado in situ ${ }^{14}$, señalizando después la deposición mediante cipos, altares y quizá incluso estelas, de los que apenas han sobrevivido ejemplos. Algunos de los hipogeos conectaban con el exterior mediante un orificio que debió servir como conducto para las profusiones típicas de las celebraciones conmemorativas periódicas.

Son tumbas a las que M. Bendala cataloga de forma decidida como neopúnicas, por su supuesta relación con el sustrato étnico y cultural "libiofenicio"

13. Una escalera planteada a la manera tradicional, o un acotado propio en el que realizar cremaciones y ceremonias conmemorativas, requerían de una superficie que no todos podrían pagar.

14. "En algunos casos, las paredes del foso crematorio disponen de uno o dos nichos, convirtiéndose en un tipo intermedio entre la tumba de cámara y la de foso, destinada ésta, salvo excepción, a un solo enterramiento" (Bendala 1995: 280). También en Carissa Aurelia se documentan tumbas de doble fosa con loculi en las paredes de la mayor (Vaquerizo 2010: 195). 


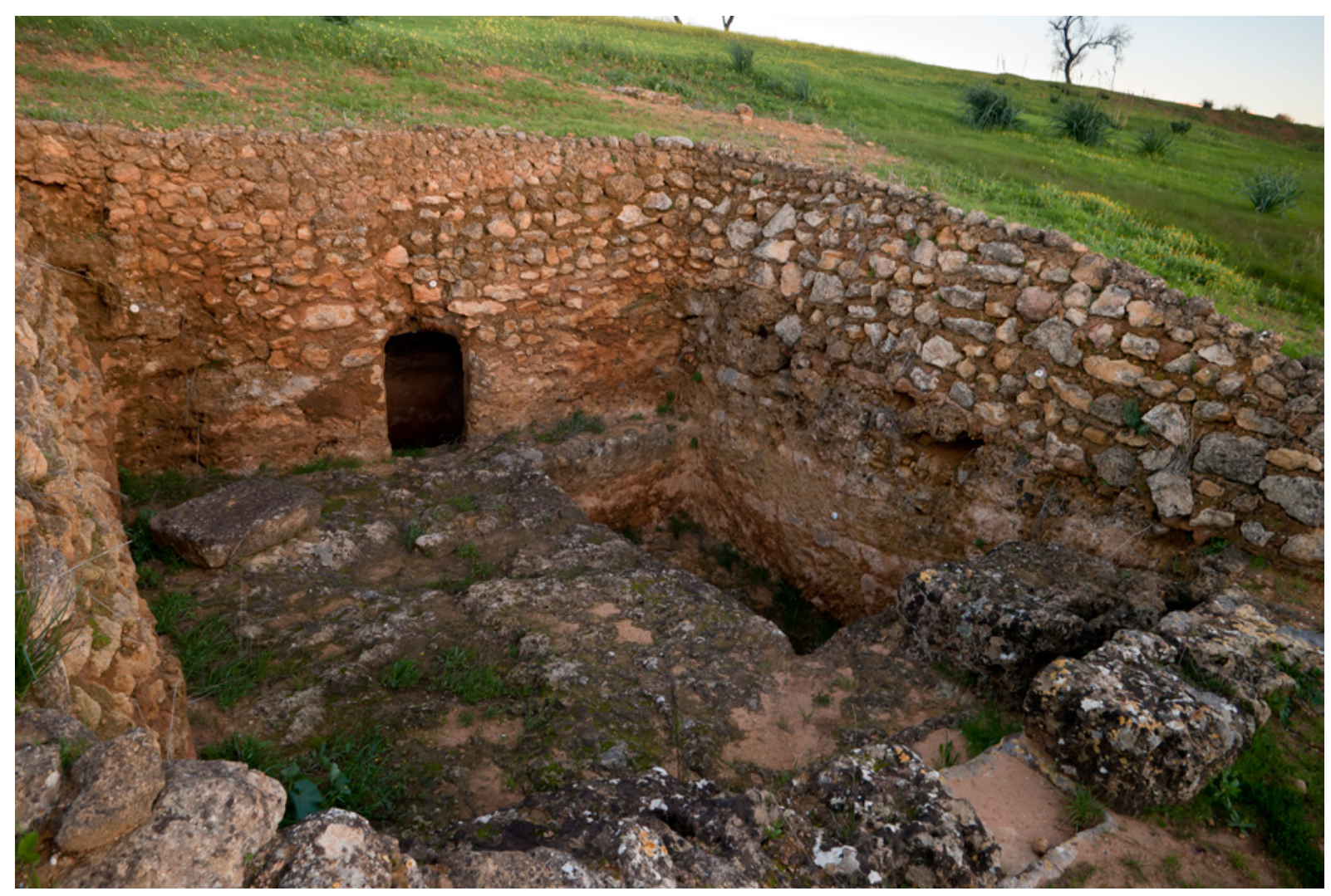

Figura 4. Necrópolis occidental de Carmona. Tumba de Prepusa (Fotog. Conjunto Arqueológico de la Necrópolis Romana).

que habría permanecido en la ciudad tras la conquista romana, y las continuas e importantes relaciones que Carmo, como otros muchos puntos de Hispania, mantendría con el norte de África tras su integración en la órbita de Roma (Bendala 1976: 39 ss.). La historia viene en apoyo de su hipótesis, dada la importancia probada de fenicios y púnicos en el devenir de la ciudad desde los inicios del primer milenio y el papel determinante desde el punto de vista político, territorial y estratégico (también, seguramente, económico) que Carmo desempeña en la zona durante la etapa de dominio bárquida. Nada se opone, en consecuencia (más bien al contrario, por cuanto las perduraciones de carácter superestructural entran de lleno en los procesos habituales de colonización), a que quedara en el bagaje sentimental de sus habitantes el gusto por un tipo de enterramiento que les era afín y cercano. Sin embargo, no se conocen tumbas de esta morfología para etapas previas a la romana, por lo que conviene no descartar la posibilidad de que, al margen del componente tradicional, las cámaras hipogeicas fueran elegidas por todo aquél que se las pudo permitir ante la fácil adaptación de su afán monumental y sus características arquitectónicas y prácticas a la roca del alcor y la vieja cantera ${ }^{15}$, al tiempo que se amortizaba un sector extraurbano de nula utilidad para usos agrícolas o ganaderos, cumpliendo de esta manera uno de los principios básicos seguidos con frecuencia por el mundo funerario de tantas otras zonas y épocas ${ }^{16}$.

15. El argumento parece perder fuerza si consideramos que la tumba de Servilia, adaptada también a la particular orografía de la cantera, eligió una tipología sepulcral diferente. Cabe, pues, en esta línea, aceptar como quiere Bendala un criterio perfectamente consciente, aun cuando sólo obedeciera a una moda más o menos coyuntural, y quizás un cierto deseo de afirmación étnica, a la hora de elegir las tumbas con cámaras hipogeicas como forma arquitectónica de carácter monumental predominante. Es una pena, a este respecto, que se hayan perdido los monumentos exteriores (cuando existieron), en más de un caso relacionados con tradiciones culturales no púnicas. Del mismo modo, recordemos que, a pesar de su relativa ortodoxia, la tumba de Servilia cuenta también con su cripta excavada en el alcor (Figura 5), por lo que el panorama está lejos de quedar resuelto, y, mucho menos, de admitir lecturas lineales. Sirva como elemento de contraste el hecho de que el anfiteatro vecino fue también vaciado en la roca, demostrando la fuerza de una práctica local absolutamente pragmática, dadas las condiciones del terreno.

16. Las mismas premisas orográficas se daban en otros sectores de la ciudad, caso por ejemplo del espacio funerario localizado junto a la puerta de La Sedía, y, en cambio, los enterramientos documentados responden a categorías formales diferentes; pero es que por la 


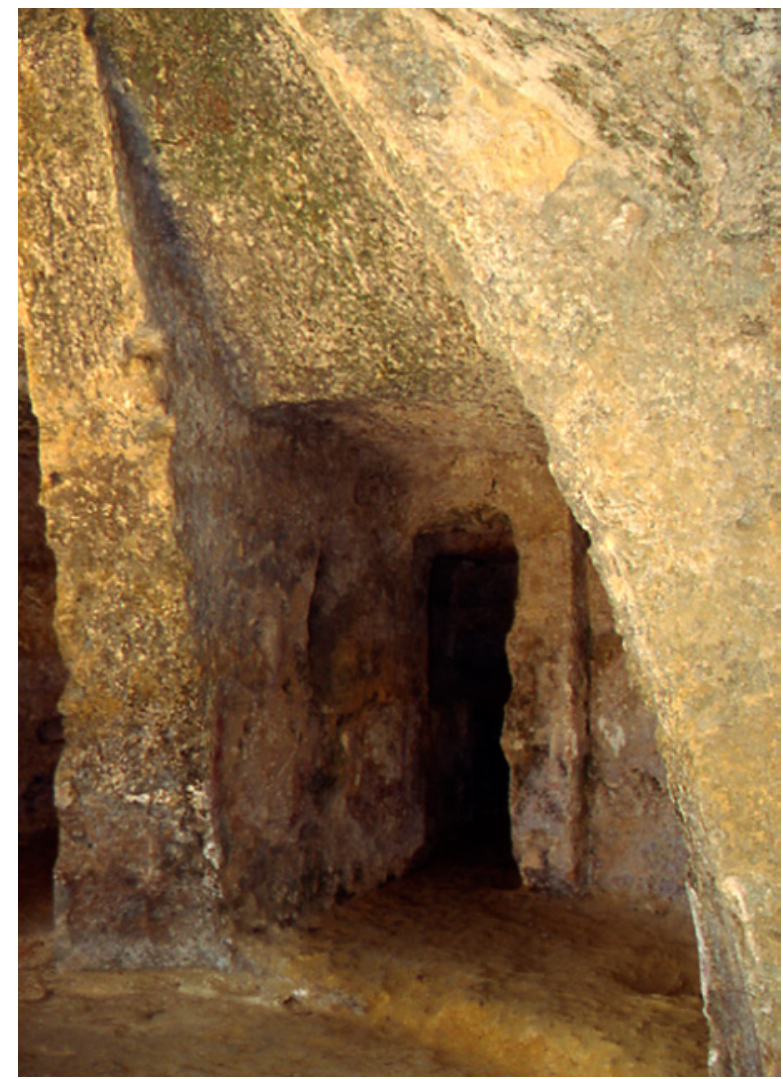

Figura 5. Necrópolis occidental de Carmona. Tumba de Servilia. Detalle del espacio abovedado que precede a la cámara funerária.

Con excepción del sellado final de los pozos, del que no se tienen pruebas determinantes, y la discutible ausencia de terra sigillata ${ }^{17}$, el ritual empleado en estos enterramientos es puramente romano.

Algunos autores (Alföldy 2001: 381 y 395) han cuestionado la interpretación tradicional de las tumbas de cámara carmonenses con el argumento añadido de la ausencia en la epigrafía funeraria local de antropónimos de filiación norteafricana. En efecto, el único nombre

zona occidental abandonaba la ciudad la via Augusta, convertida por definición en el mejor escaparate para la autorrepresentación de los carmonenses. Es preciso, pues, tener en cuenta también el componente ideológico (Amores 2001: 455).

17. De la que se habría prescindido, supuestamente, por constituir un símbolo explícito de romanidad, en beneficio de la tradición y los valores autóctonos, de fuerte sustrato púnico (Vidal y Campos 2006: 28 ss., lám. IX). No obstante, de ser así, ¿por qué no se hizo con otros materiales como las ánforas grecoitálicas o las cerámicas campanienses, que sí se documentan en los ajuares de los primeros siglos? Eso, por no hablar de los numerosos objetos de importación que nutrieron siempre los ajuares funerarios gaditanos.. indígena documentado en toda la necrópolis occidental sería el del peregrinus Attita, de base turdetana, ya que el tradicionalmente interpretado como Urbanival podría admitir otra lectura: Urbani Val(eriorum) (servi). Tal vez el proceso de asimilación lingüística fue tan rápido que acabó pronto con los antropónimos de raíz autóctona (Díaz Ariño 2008: 69). Sin embargo, tal aseveración parece contradecirse con los procesos ordinarios de hibridismo cultural ${ }^{18}$ (más aún en el caso de Roma, que respetó siempre la personalidad de los pueblos sometidos) y su constatación bien comprobada en otros núcleos urbanos de la Bética ${ }^{19}$. No hay que descartar, por tanto, que muchos indígenas mantuvieran sus propias formas de enterramiento durante los primeros siglos de la ocupación romana, aunque en la mayor parte de los casos no conozcamos ni las suyas ni la de los conquistadores y colonos.

Estas nuevas propuestas de lectura han afectado de manera especial a la denominada Tumba del Elefante (Figura 6, A y B), fechada en la primera mitad del siglo I d.C. y valorada por M. Bendala como un santuario a los dioses frigios Attis y Cibeles con argumentos sobradamente conocidos, en los que no me detengo (Bendala 1976: 49 ss., láms. X-XVI; 1995: 281). En contraposición, otros autores (Fear 1990; Alföldy 2001; Salza Prina 2004: 236) la consideran una simple tumba monumental de carácter familiar, dotada de cepotaphium y estancias diversas para las ceremonias y banquetes conmemorativos, incluidos cocina y pozo, adaptadas a la peculiar topografía del lugar y decoradas con motivos iconográficos al uso. Entre ellos, la supuesta figura de Attis, que como el resto de representaciones suyas identificadas en la necrópolis (Bendala 1976: lám. LIII, 2-4), obedecería más a un motivo

18. Basta por ejemplo pensar en lo ocurrido en América Latina tras la presencia española de varios siglos, probablemente más traumática desde el punto de vista poblacional que la romana en Hispania.

19. Destacan, además del Aurelius Vgaiddillus de Italica (Caba1los, 1994, 229 ss., láms. V ss.); el duunviro M. Horatius Bodolinur, de Urgavo (CIL II/7 91; Baena del Alcázar y Beltrán 2002: 71 ss., $n^{\circ}$ 4, fig. 21) (Figura 7); el C. Iulius Aeturus Solicum, ciudadano romano con cognomen añadido de filiación indígena cuyo titulus sepulcralis apareció en Navas de Estena, al Sur de los Montes de Toledo (Alföldy 1998: 292), o los inscritos sobre algunas de las urnas cinerarias de piedra recuperadas en la provincia, entre las cuales reviste un interés especial el conjunto de Torreparedones (Castro del RíoBaena, Córdoba), con una cronología comprendida entre mediados del siglo I a.C. y mediados del siglo I d.C., de raigambre turdetana y, en este caso sí, posiblemente púnica: Icctnis, Aninna, Nanna, Velaunis, Ildrons, Igalghis, Insghana, Sisean, Bahanno y Velgana (Rodríguez Oliva 2002: 270 ss., láms. V y VI; Díaz Ariño 2008: 68 ss. y 226 ss., U41 ss.). Gracias a Ana B. Ruiz Osuna por algunas de las referencias. 

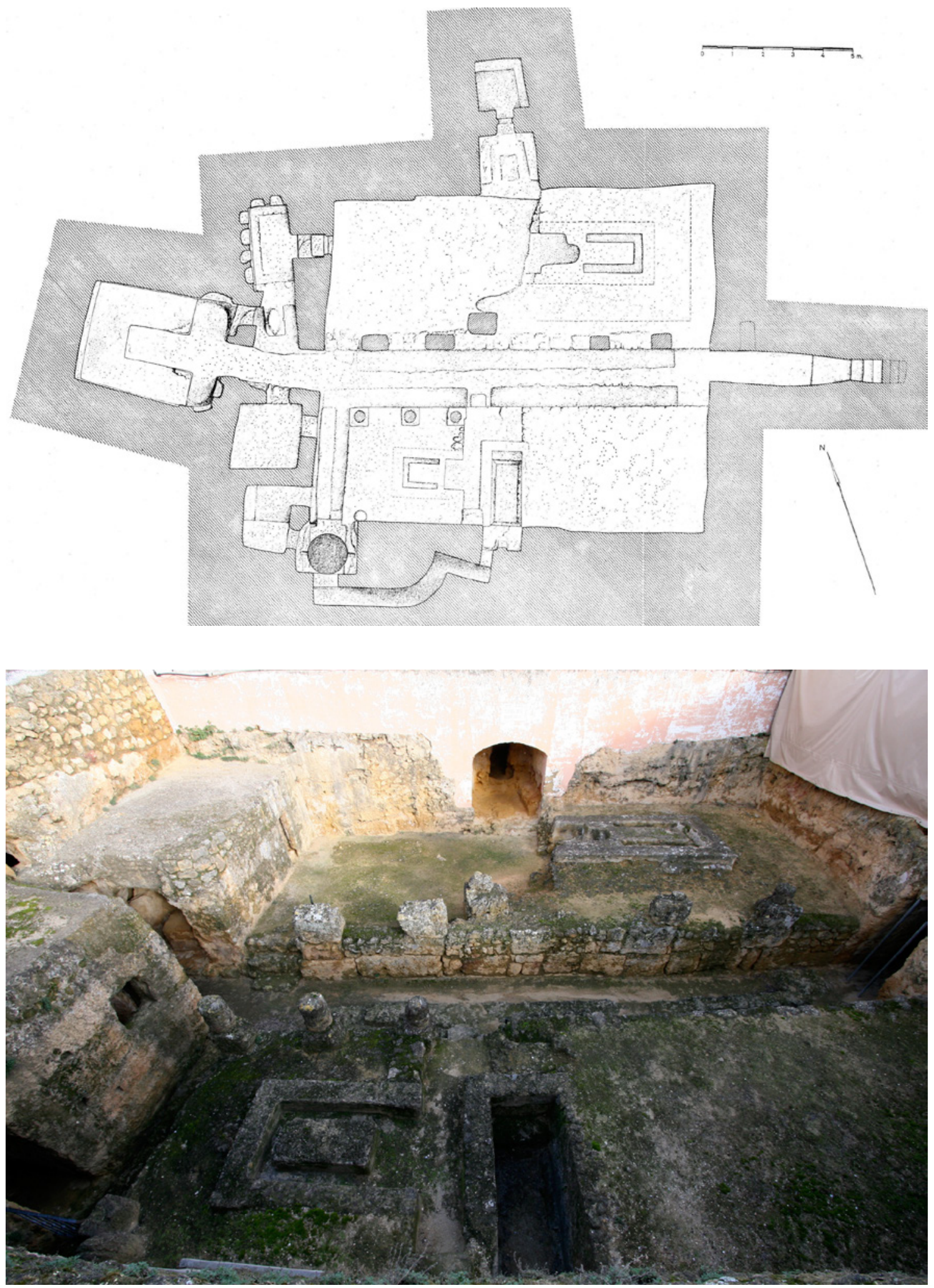

Figura 6. Necrópolis occidental de Carmona. Tumba del Elefante. A) Planta (Bendala 1976, II, Lám. XI). B) Vista de su estado actual (Fotog. Conjunto Arqueológico de la Necrópolis Romana). 


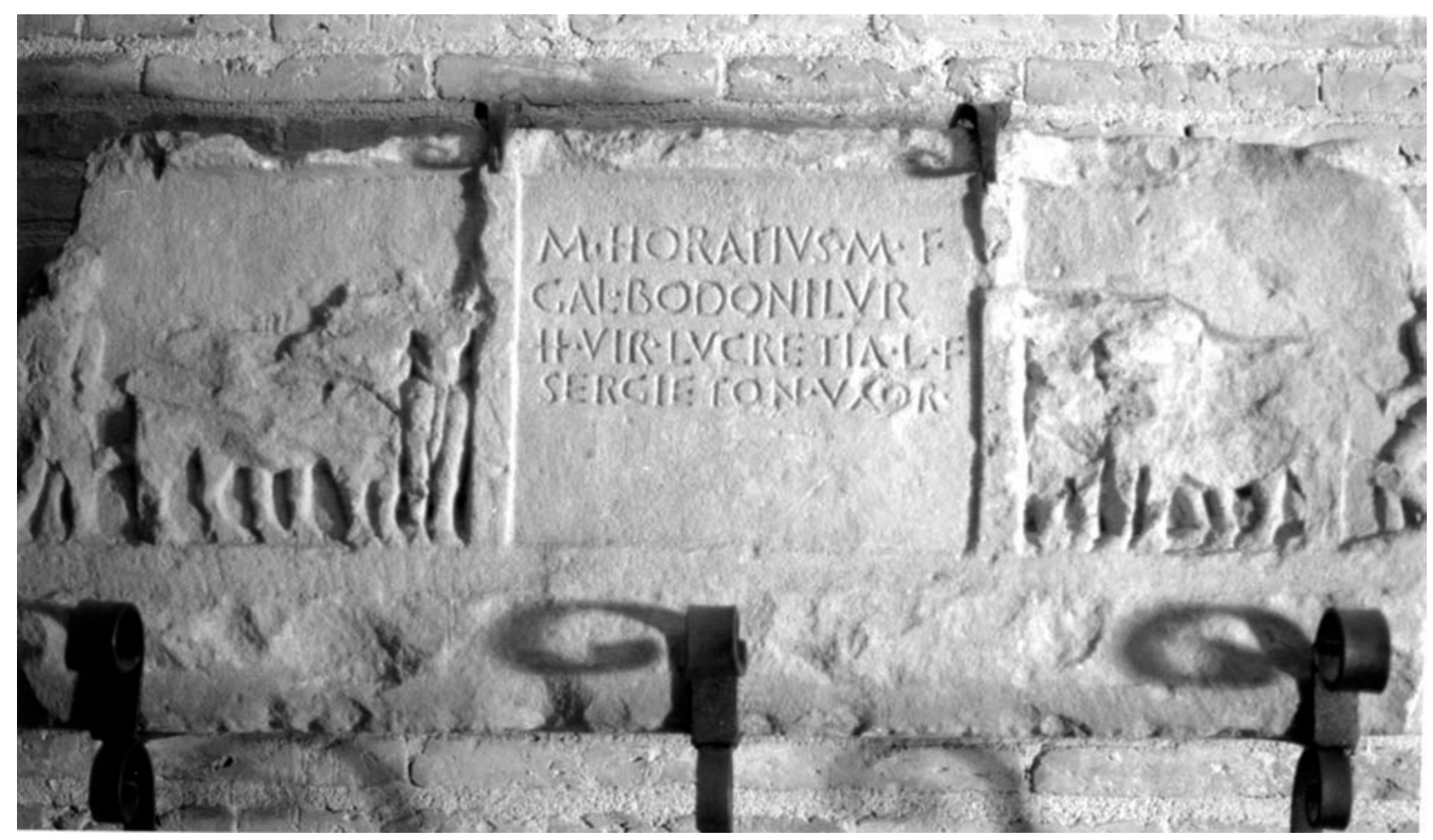

Figura 7. Urgavo (Arjona, Jaén). Monumento funerario del duunviro M. Horatius Bodolinur (CIL II²/7, 91).

de repertorio (piangenti, o esclavos orientales, propios de ambientes funerarios o celebrativos), que a una imagen religiosa en sentido estricto, y el tradicionalmente interpretado como sacerdote de Cibeles (Bendala 1976: lám. LV, 1 y 2), al parecer sedente y capite velato, que sería la representación de uno de los difuntos enterrados en el monumento: el pater familias o el comitente del mismo, en el acto de realizar una libación; algo a lo que Bendala se opone, con argumentos prolijos y razonados (Bendala 1990: 113).

Se trata, en cualquier caso, de un nuevo punto de vista, que podría verse reforzado por la existencia de tumbas de cierta similitud en cuanto a cronología, estructura y concepto (mutatis mutandis, por cuanto, aun cuando relativamente complejas, son recintos de obra, en lugar de monumentos hipogeicos, y cuentan con un solo triclinium) en necrópolis tan ortodoxas y "romanas" como son por ejemplo las de Ostia (Heinzelmann 2000: 44-45, 64 ss., 262 ss., Abb. 26, 165 o 169). Así las cosas, cabría también interpretar el óculo de la cámara principal simplemente como lucernario, destinado a proporcionar aire e iluminación a un espacio que sólo contaba al efecto con él y la puerta, pero tales hipótesis no explican la morfología tan extraña del edificio, su orientación, que obligó a desplazar el eje general del conjunto, el diferente tamaño de los triclinia, su posible carácter cubierto, la complejidad de cámaras y dependencias, la falta de un jardín en sentido estricto, o los sofisticados dispositivos acuáticos de que fue dotado (por no hablar de los condicionantes ajenos al conjunto introducidos por su habilitación para la visita), argumentos importantes todos ellos en la interpretación de M. Bendala (2002c: 75 ss.). Como lo son, en la misma medida, el papel protagonista reservado a la figura tallada en piedra local del elefante, para este autor símbolo del sol y longevidad, en una concepción de clara raigambre norteafricana (Bendala 1976: 61 ss.), mientras para G. Alföldy y W. Trillmich se trataría sencillamente de un elemento de carácter exótico al que cabría buscar otros significados (Alföldy 2001: 384) $)^{20}$, o la complejidad ideológico-religiosa que implica el betilo, en el que Bendala cree poder identificar a Cibeles. Es importante recordar, a este respecto, la presencia frecuente de piedras más o menos talladas colocadas junto a los enterramientos en Baelo Claudia (Vaquerizo 2008a). Estos betilos empiezan a proliferar en Carmona (Figura 8), para etapas

20. Tras estas nuevas propuestas de lectura, Bendala ha insistido en su hipótesis, rechazando de plano y de manera profusamente justificada los argumentos utilizados por sus detractores (Bendala 2002b: 144 ss.; 2002c: 76-77, y 80 ss.). 
anteriores y en contextos diferentes, con un componente esencialmente ritual (Belén, Conlin y Anglada 2001; Bandera et alii 2004) $)^{21}$.

A todas estas opiniones han venido a sumarse en los últimos años la de J. Beltrán, que vuelve sobre la idea de lugar de culto a divinidades orientales, añadiendo como argumento la proximidad de la tumba al coliseo carmonense, donde a su juicio debió ubicarse un $\mathrm{Ne}$ meseum, a la manera de los documentados en los anfiteatros de Italica, Tarraco y Emerita (Beltrán Fortes 2008a), y la de J. Alvar, que comparte y rechaza a la vez según qué argumentos de unos y de otros, concluyendo que mientras la investigación arqueológica no aporte algún dato nuevo de relevancia la razón podría estar de cualquiera de las partes, supuesta "la falta de consistencia de los elementos empleados en la construcción del imaginario" (Alvar 2007: 97). Una idea que comparto, en líneas generales, por cuanto ninguna de las nuevas hipótesis ha sido suficientemente argumentada (Bendala 1990: 114; 2002c: 76 ss. $)^{22}$.

Por el momento, sólo queda clara la enorme complejidad tipológica de los enterramientos practicados en la necrópolis occidental de Carmo, en absoluto limitados a las tumbas de cámara que la hicieron internacionalmente conocida, y lógicos por otra parte en un cementerio que permanece en uso entre los siglos II a.C. y VII d.C., evidenciando modificaciones en su paisaje funerario similares a las que han sido observadas en otras ciudades del Imperio. Será preciso, pues, continuar haciéndose preguntas, seguir trabajando en la interpretación de la necrópolis y del monumento, que a pesar de todo lo que se ha escrito sobre ellos continúan pendientes de lectura definitiva; circunstancia que da idea de la complejidad derivada de este tipo de expresiones culturales, en las que lo material trasciende claves ideológicas extremadamente difíciles de desentrañar desde nuestra óptica y con los datos disponibles.

21. La problemática del betilismo en la Península Ibérica ha sido revisada recientemente por I. Seco Serra en su Tesis Doctoral (2002), que he tenido el privilegio de consultar por cortesía de su autora, y ha visto la luz después de entregar estas páginas (Seco 2010).

A ella remito para un análisis en profundidad de la problemática, incluidos los casos de Carmona (308 ss.) y Baelo (367 ss.). Sobre el tema, vid. también Rossignoli (1992).

22. "Sin duda que existen problemas de lectura, pero no se pueden resolver por simplificación, ni por la eliminación o el añadido de aquello que convenga a la hipótesis de partida. Es, qué duda cabe, un monumento anómalo. Pero las anomalías resultan tales por contraste con las referencias que se tienen por canónicas o válidas..." (Bendala 2002c: 77).

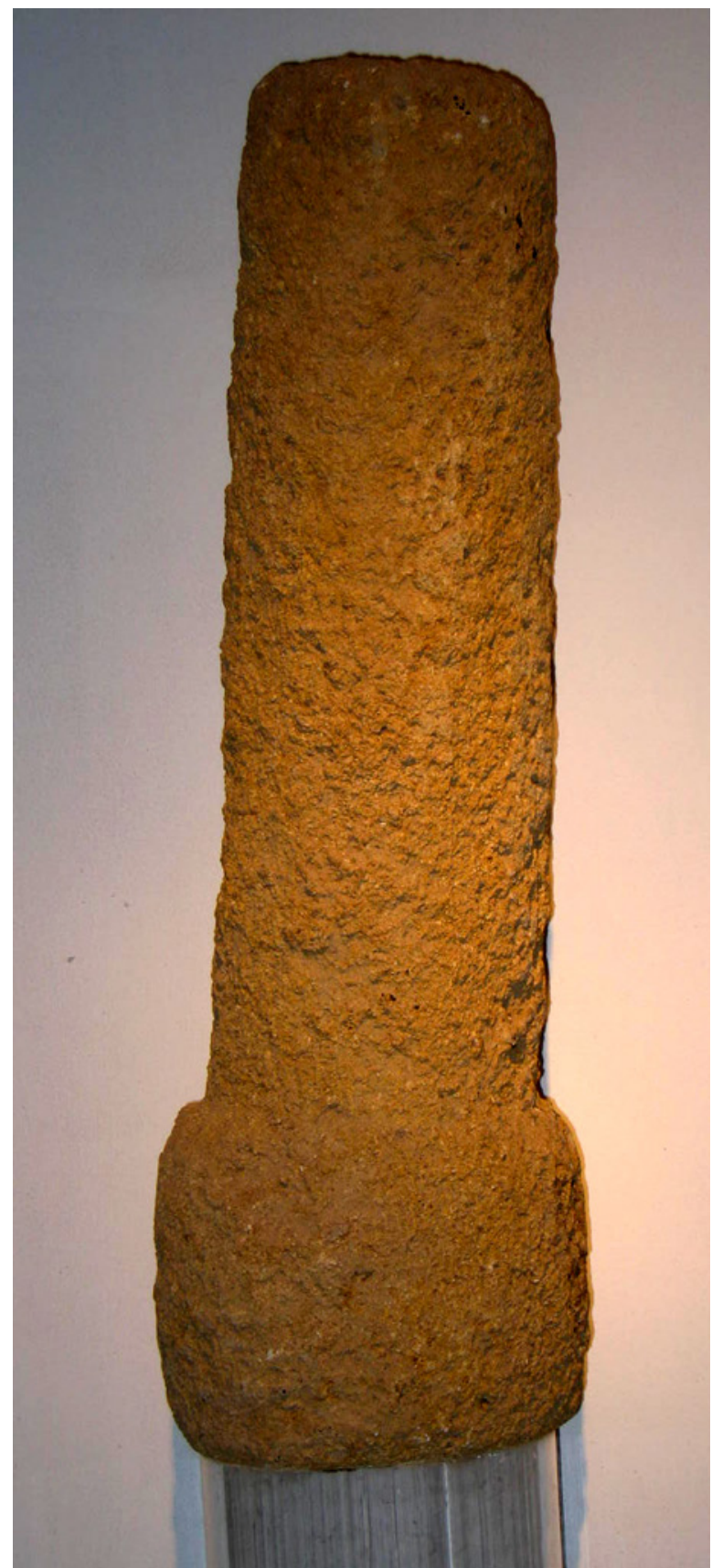

Figura 8. Carmona. Betilo procedente de la calle Pozo Nuevo. Museo Arqueológico de la ciudad.

\section{Corduba}

En Corduba, capital de la provincia desde el mismo momento en que ésta se configura como tal, y si bien es cierto que las necrópolis de época republicana nos siguen siendo esquivas, las primeras manifestaciones 
funerarias de que disponemos hasta la fecha son ya plenamente romanas (vid. al respecto Vaquerizo 2010a y Ruiz Osuna 2010). No detectamos más resabios indígenas que el uso de algunas urnas cinerarias pintadas conforme a la vieja tradición ibero-turdetana ${ }^{23}$, y quizás el gusto por cámaras hipogeicas o semihipogeicas (en el caso de Córdoba siempre con recinto y monumento supraestante) selladas mediante bloques pétreos ${ }^{24}$ que, en opinión de M. Bendala, supondrían un "cegamiento arquitectónico" equiparable al de otras tumbas norteafricanas, o hispano-púnicas (Bendala 1976: 1995, 279-280, y 2002b: 149 ss.) $)^{25}$. Hasta el momento, tales cerramientos han sido documentados en los monumentos funerarios de Camino Viejo de Almodóvar, C/ La Bodega y Palacio de la Merced (los dos primeros obra seguramente de un mismo taller, especializado en este tipo de construcciones), ya publicadas de manera repetida (Vaquerizo 2001, 2002 y 2006; Ruiz Osuna 2010), por lo que no tiene demasiado sentido insistir en el tema, salvo quizá para recordar que el primero de ellos podría haber ido coronado por un monumento en forma de altar, a la manera, por ejemplo, de algunos de los que todavía hoy pueden contemplarse en la Puerta de Herculano, en Pompeya. A este respecto, conviene destacar que, como ocurría en la necrópolis occidental de Carmo, el ritual documentado es, sin excepción, plenamente romano.

Destaca además el hallazgo reciente de una cupa solida reutilizada en el complejo arquitectónico del foro provincial (Vaquerizo 2010a: 121 ss., Fig. 81) (Figura 10), que confirma la existencia en la ciudad de este tipo de monumentos tan controvertidos, objeto de

23. Quizá, sencillamente, un producto de talleres locales más accesible y a mejor precio que el material de importación, no siempre disponible. A. Jiménez las considera "elementos herederos de ... época prerromana que confieran a las necrópolis de la capital de la Bética un carácter híbrido característico de situaciones coloniales" (Jiménez Díez 2005: 385), en una interpretación, a mi juicio, excesivamente determinista.

24. Posible adaptación local del mundo romano más normativo, entendidas como modelos de prestigio al servicio de las aristocracias provinciales, en más de un caso de origen vernáculo.

25. También, la posible estela funeraria de tipología claramente fenicio-púnica, recuperada en 1947 en plena C/ Cruz Conde y conservada actualmente en el Museo Arqueológico y Etnológico Provincial ( $\mathrm{N}^{\mathrm{o}}$ inv. 9801). Tallada en piedra local, tiene forma troncocónica y presenta en relieve una palmera y un altar escalonado, conforme a claves iconográficas bien conocidas en ambiente púnico occidental (Seco 2010, 355 ss.) (Figura 9, A y B). De cronología y funcionalidad inciertas, podría haber servido en un espacio sacro ubicado en ambiente termal, pero parece más bien tratarse de una reutilización como simple material arquitectónico. En cualquier caso, es el único elemento de estas características documentado hasta la fecha en Córdoba, y uno de los más singulares de la Península Ibérica. un trabajo monográfico por mi parte (Vaquerizo 2006), más tarde actualizado (Vaquerizo 2010: 300 ss., Fig. 275), donde planteo algunas reflexiones sobre su filiación cultural y su cronología de las que retomo algunas aquír ${ }^{26}$.

\section{Cupae y bóvedas de ladrillo}

Cupae solidae, cupae structiles (Figura 11, A y B) y bóvedas de ladrillo fueron formas sepulcrales usadas por gentes que debieron hacer de ellas un signo de autodeterminación social, cultural y en algún caso también de identificación étnica, por lo que de alguna manera pueden ser entendidas como peculiaridades provinciales o regionales de un fenómeno mucho más amplio, entroncado en último extremo con la "globalización" cultural que implica lo que en términos genéricos se ha conocido tradicionalmente como "romanización". Por eso, estoy de acuerdo con $\mathrm{Ch}$. Tupman cuando resta importancia al origen concreto de la forma en cada una de las zonas donde se emplea (incluida la propia Italia), ya que un tipo de monumento que estuvo en uso tres o cuatro siglos lo más seguro es que acabara cobrando su propio significado, no necesariamente igual, ni siquiera derivado, del que tenía en el momento de su introducción (Tupman 2005: 125). No niego, pues, la pervivencia de valores indígenas que en algunos casos incorporarían un matiz púnico, ni la existencia de contactos permanentes con el norte de África ${ }^{27}$, que se canalizarían entre otras vías a través de Tarraco, adonde llegarían por la vía de las islas, y Baetica, a la que irradiarían desde las ciudades costeras, como Baelo o Carteia, y aquéllas en las que el recuerdo púnico se mantuviera más vigente (Carissa Aurelia, Carmo, Urso, quizá Corduba....); ni tampoco el intercambio continuado en el tiempo de individuos, muchos de ellos militares, o miembros de la Administración, a pesar de que la epigrafía resulte tan esquiva al respecto (García y Bellido 1959: 144 ss. $)^{28}$. Baste recordar, desde

26. El interés por este tipo de monumentos funerarios se concretó en 2010 con la celebración de un congreso monográfico en Uncastillo (Zaragoza), bajo la coordinación de Javier Díaz Andreu, cuyas aportaciones verán seguramente la luz en pocos meses. A ellas remito para las novedades y últimas teorías en relación con el tema, de las cuales se pueden encontrar también una síntesis en Baratta 2006.

27. Así lo testimonian las fuentes literarias y la numismática, además del intercambio comercial sostenido (Gozálbes Cravioto 2006: 1337 ss.).

28. Contamos, a pesar de todo, con algunos tituli que testimonian de forma más o menos directa los contactos continuados y fructíferos, lógicos por otra parte, entre ambos continentes (el llamado Círculo 

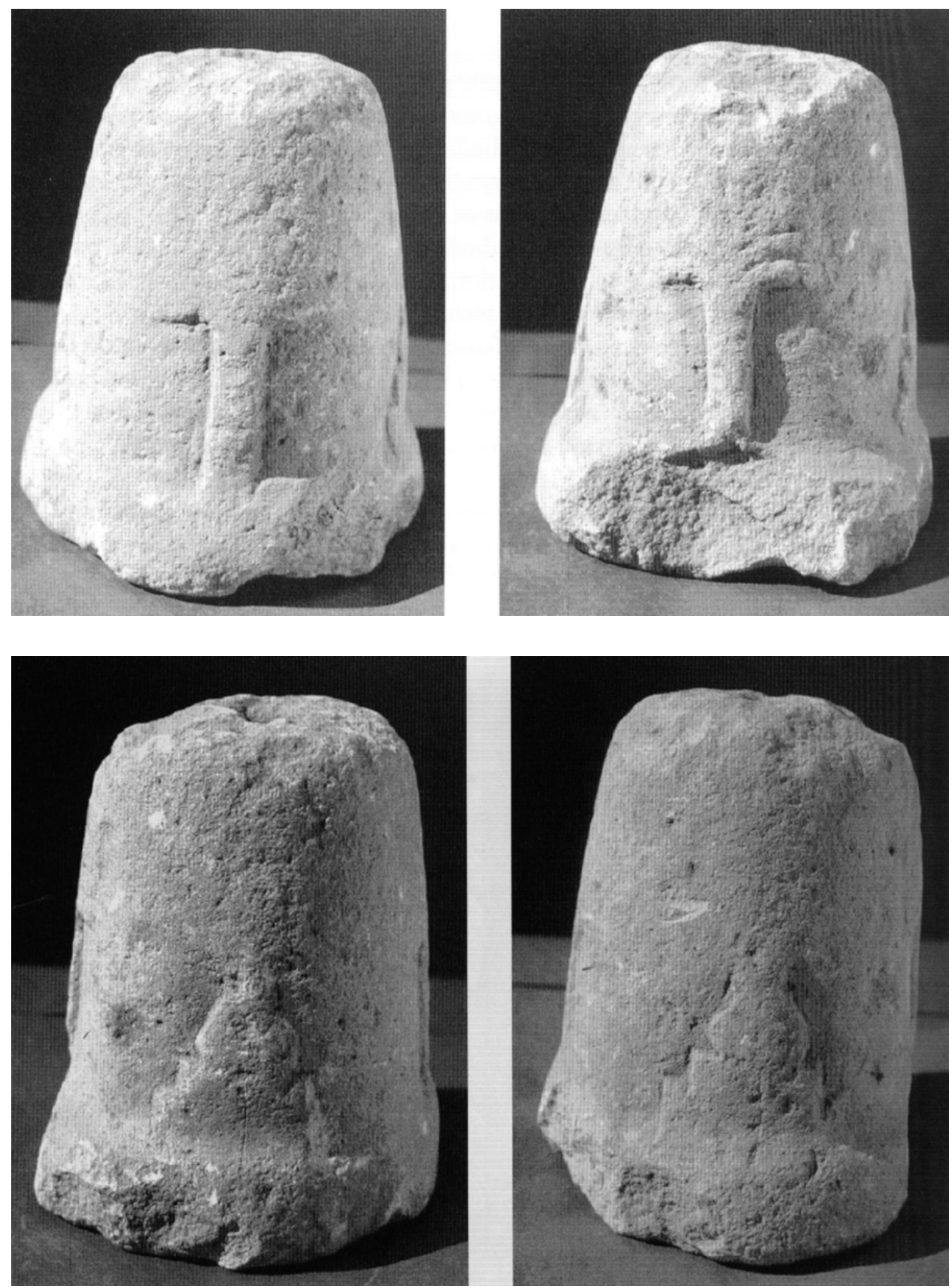

Figura 9: Corduba. A y B) Posible betilo o, mejor, estela funeraria, con representación en relieve de palmera y altar escalonado. Se conserva en el Museo Arqueológico Provincial (Seco 2010, Figs. 192-193 y 196-197). 


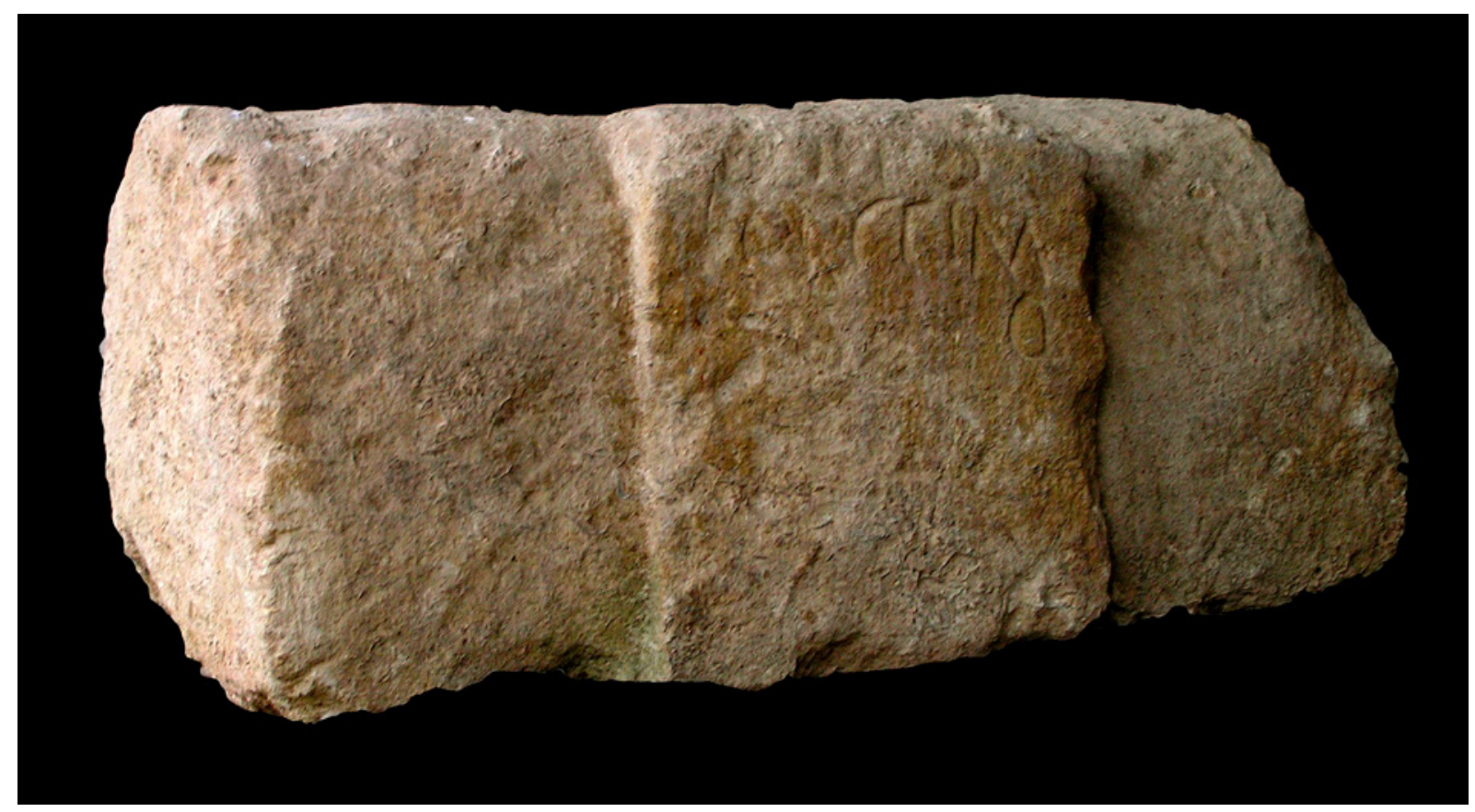

Figura 10. Corduba. Cupa solida reutilizada en una refectio del forum provinciae (Fotog. A.B. Ruiz Osuna).

este punto de vista, la documentación en algunas de las ciudades citadas de divinidades con advocaciones claramente africanas ${ }^{29}$, o las relaciones institucionales (y humanas, culturales, comerciales...) habituales entre ambas provincias, que llegaron incluso a formar parte de la misma demarcación administrativa. Pero todo ello no es suficiente para identificar sin más los enterramientos en tumbas de cámara, cupae (en cualquiera de sus tipos) o bóvedas de ladrillo, con gentes de origen, procedencia o ascendencia directa africana.

Por el contrario, y a pesar del éxito innegable, masivo, que algunas de estas manifestaciones funerarias -particularmente las cupae - tuvieron en numerosas ciudades norteñas del continente vecino, en mi opinión sería

del Estrecho), particularmente entre Baetica (Baelo Claudia, Conobaria, Corduba, Gades, Italica, Singilia Barba...) y Mauretania Tingitana (Lixus, Sala, Tabernae, Tamuda, Tingis, Volubilis...); alguno de ellos de carácter funerario (faceta en la que llama la atención además la identidad de algunas fórmulas entre ambas provinciae). Es el caso de Valeria Bastula, cordubense y madre del militar Valerius Severus, eq(ues) alae Gemelliana, que se trasladó con él a Tingis, donde murió con ochenta años (Gozálbes Cravioto 2006: 1343, fig. 4).

29. Así, el ara conservada en el Museo Arqueológico de Córdoba, procedente al parecer de la propia capital (aunque no se descarta su posible origen obulconense), dedicada por Tiberius Claudius Dionis a la Nutrix Augusta, divinidad púnica no documentada fuera de África. Su cronología se va a los años finales del siglo I d.C., o bien a los iniciales del siglo II d.C. (CIL $\left.\mathrm{II}^{2} / 7,223\right)$. más exacto hablar de maneras particulares de entender el tumulus que en ciertos momentos, y de forma especial en algunos núcleos urbanos del occidente del Imperio, por razones que sería preciso analizar con detalle en cada caso, gozaron de gran popularidad y predicamento entre ciertas clases sociales: en su mayor parte, pequeños comerciantes, artesanos, libertos, esclavos ${ }^{30}$ y algún militar, que encontraron en ellas una forma más o menos barata de "monumentalizar" sus enterramientos, con independencia del rito utilizado, $y$, en apariencia, un modo bastante eficaz de singularizarse frente a los tipos funerarios romanos más normativos ${ }^{31}$. En Hispania las $\mathrm{Cu}$ pae aparecen relacionadas, casi en exclusiva, con gentes de condición servil. Así, en Barcino, dos terceras partes de los esclavos que recibieron un monumento funerario ${ }^{32}$ fueron conmemorados con cupae (Tupman 2005: 131)

30. Aun cuando no falta algún individuo de condición ingenua, esclavos y libertos son, de hecho, los usuarios mayoritarios de las tumbas "a cassone" en la necrópolis de Isola Sacra (Taglietti 2001: 155).

31. Esto no evita que en más de un caso las tumbas rematadas con bóvedas de ladrillo fueran embutidas en fosas excavadas en el terreno de las que apenas sobresaldrían, lo que parece limitar de manera considerable su condición de monumento visible. Así ocurre por ejemplo en Munigua (Schattner 2003: 101 ss.; Figs. 68-76, Láms. 53-59; Vaquerizo 2010: 263 ss.), o Astigi (Figura 12, A y B).

32. A veces, pagados por ellos mismos, lo que demuestra un poder adquisitivo por su parte reñido con el estereotipo que representan. Sobre el tema, vid. también Rodá (1989: 101). 


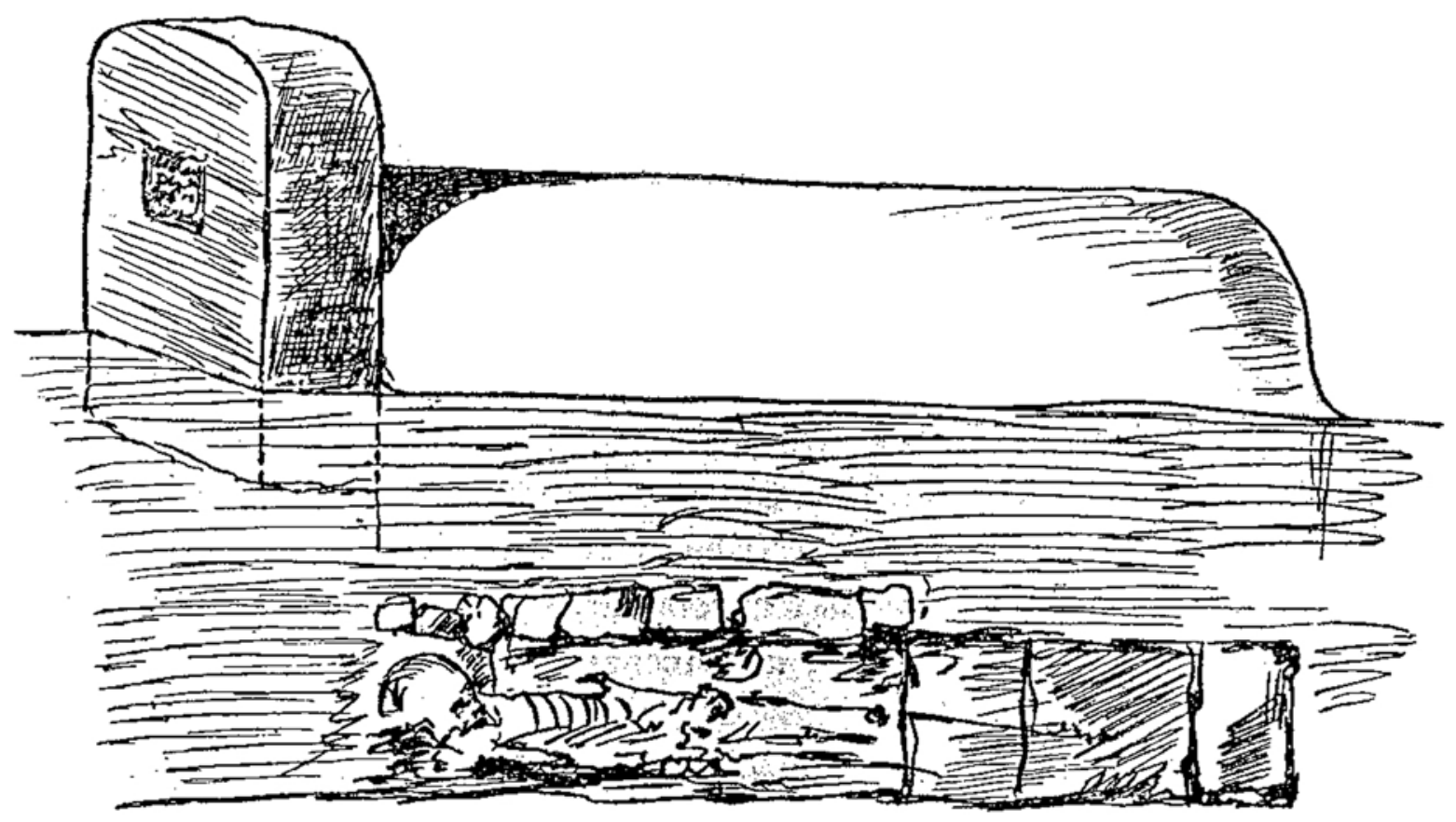

Figura 11. A) Necrópolis de Cádiz. Cupa structilis de M. Faustilius Faustilius (Quintero

Atauri 1932, 25). B) Corduba. Barriada de Santa Marina (Necrópolis Oriental) Posible cupa strucilis, único ejemplo conocido hasta el momento en la ciudad. Inédita (Fotog. A.J. González Ruiz).

No hace falta decir que negar su utilización ocasional por parte de gentes de procedencia estricta norteafricana, o relacionadas en una u otra forma con esta región, desde donde podrían haber trasladado el gusto familiar por tales formas de enterramiento, o comprobado personalmente su enorme difusión, sería temerario. No se trata de eso; entre otras cosas porque muchas de estas gentes nutrirían aquellas clases sociales de las que hablaba un poco más arriba, y porque en el fondo todos se integraban bajo la órbita de Roma, formada culturalmente en el mismo marco del Mediterráneo occidental del que había mamado nuestro sur peninsular. No olvidemos que la elección del tipo de tumba en el mundo romano dependía sobre todo de la capacidad económica, y en ocasiones de la posición social, más que del carácter étnico, interviniendo sólo a partir de ellas las preferencias

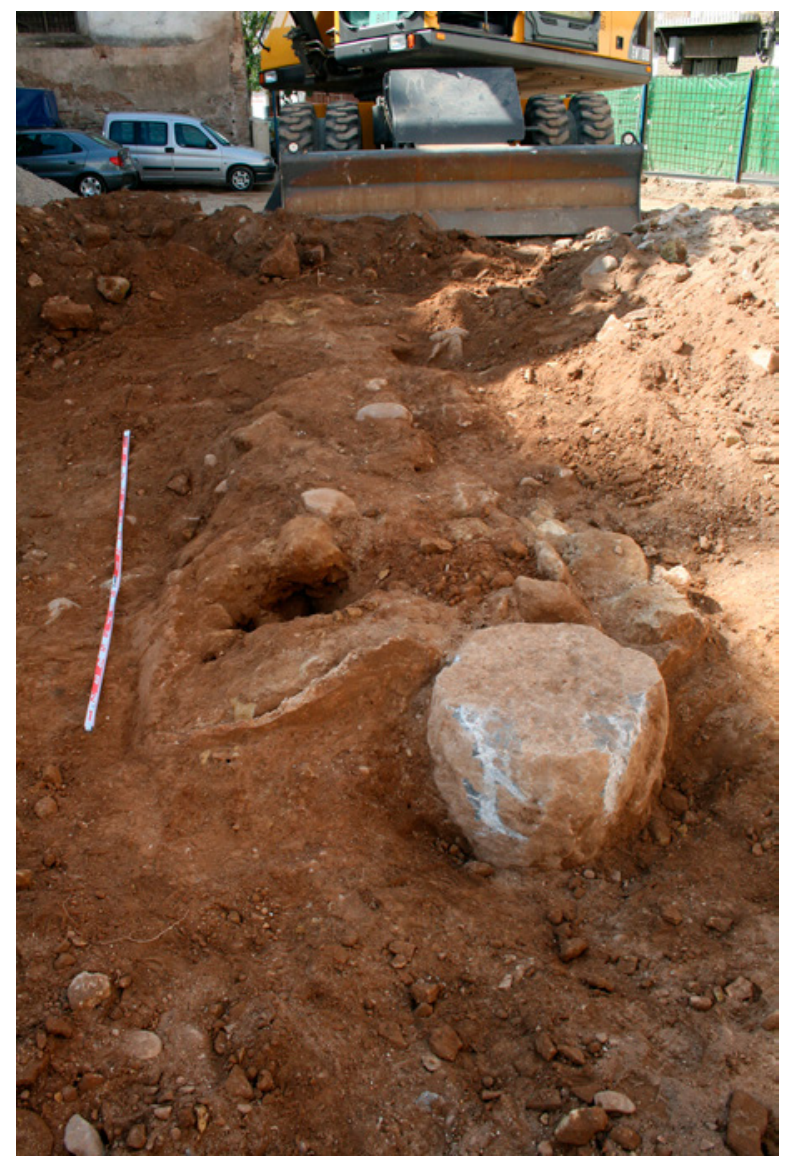



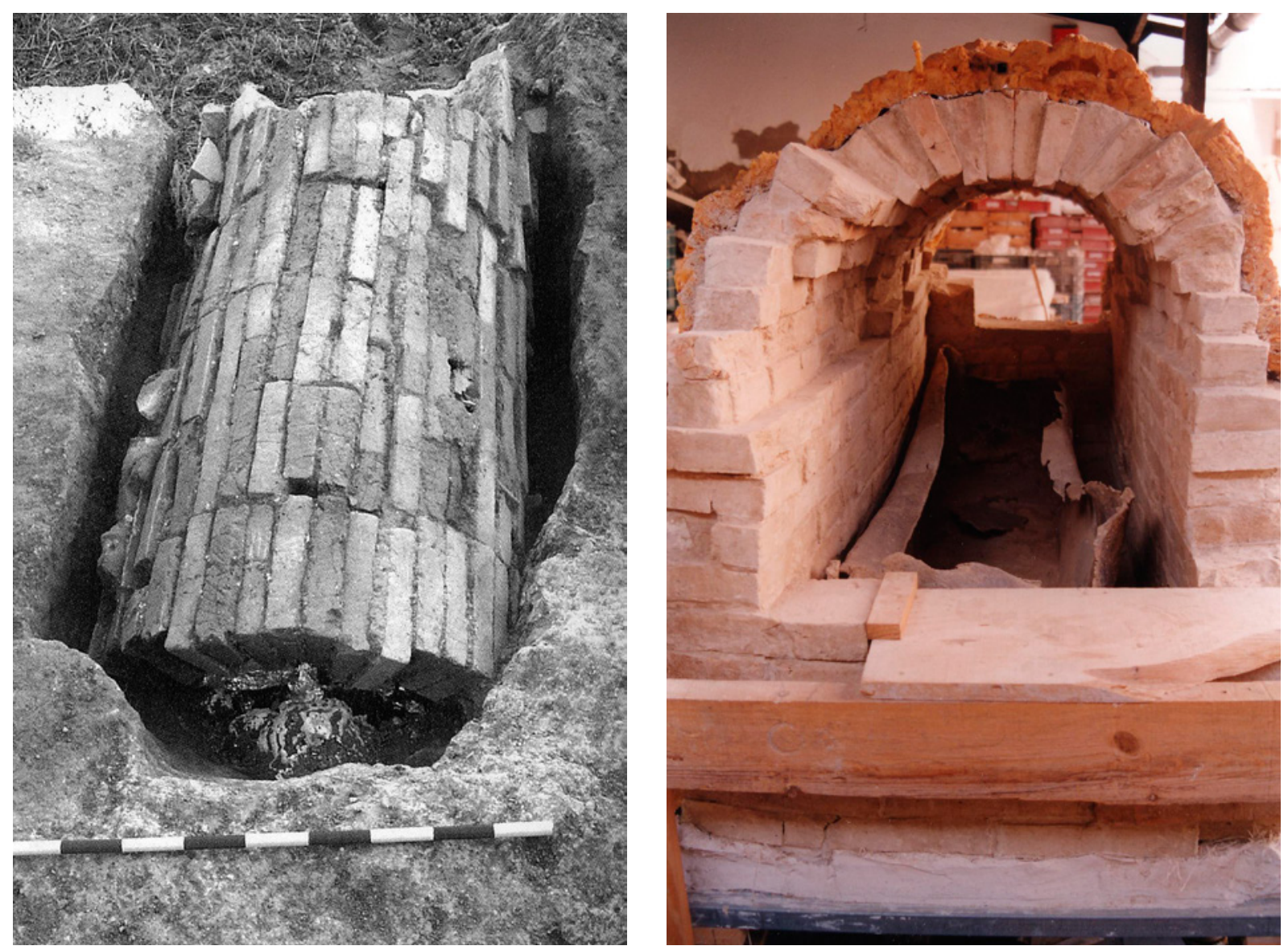

Figura 12. Astigi. Enterramiento bajo bóveda de ladrillos. Carretera de Herrera. Km. 59,2. A) Tumba in situ, con la estructura latericia embutida en la fosa (Fernández Ugalde, Martín 2006, Lám. 3). B) Estado actual, en el Museo de Écija.

individuales (Calza 1940: 49), pero también que la tumba fue elegida desde muy pronto para dejar testimonio público y explícito de romanidad.

\section{Monumentos con leones}

Problemática es igualmente la interpretación de los monumentos tardorrepublicanos con leones localizados en ciudades como Carissa Aurelia (Pérez López 1999: 48 ss., $\left.n^{\circ} 8-10\right)^{33}$ y algunas otras cercanas (Pérez López

33. A los varios ejemplares de Carissa (Figura 13), se suman otro de Villamartín-Bornos, y diez más del entorno de Espera (Pérez López 1999: 48 ss., nº 8-20), lo que supone una acusadísima concentración del modelo. De la primera procede además una esfinge, inédita, conservada también en el Museo Arqueológico Provincial de Cádiz y de cronología aparentemente romana, a la que se otorga el mismo significado funerario (Pérez López 1999: 12, Nota 24) El resto de las ciudades hispanobéticas han proporcionado por lo
1999: 54 ss., $\left.n^{\circ} 11-20\right)$, tallados todos en caliza blanca local $^{34}$, quizá revestida de estuco e incluso policromada. Testimonian una considerable proliferación del tipo en la zona (Figura 14) ${ }^{35}$, en relación fundamentalmente con necrópolis urbanas, y parecen evocar expresiones similares de filiación prerromana (púnico-helenística) en

general un solo ejemplar, con algunas excepciones, como Urso o Conobaria (Beltrán Fortes 2008b: 504 ss., láms. 1-3). Seguramente influye en todo ello la aleatoriedad de los hallazgos arqueológicos.

34. Sólo en Astigi (Cfr. Baena Del Alcázar y Berlanga 2006: 70) y en Mérida se han documentado leones labrados en mármol, estos últimos de cronología augustea (Pérez López 1999: 11, nº 52 y 53). .

35. No ofrecen la misma distribución geográfica los leones que sujetan bajo sus garras una cabeza de carnero, de ternero o de cervatillo, que los que exhiben como trofeo una cabeza humana. Mientras los primeros se concentran en la margen izquierda del Guadalquivir, los últimos lo hacen en el curso alto o medio del mismo. Su distribución en el territorio podría ser un reflejo del avance y la procedencia diversa de los colonos, u obedecer a razones simbólicas o religiosas (Pérez López 1999: 18 ss., y 22 ss.). 
su concepción como expresión de poder y su técnica ${ }^{36}$, pero itálicos en cuanto a sus modelos, como se observa, por ejemplo, en la cabeza, animal o humana, que muchos de ellos sujetan con una de sus zarpas, en una evocación muy particular de la muerte.

Estos leones (habitualmente por parejas) coronaron en origen un tipo de monumentum muy sencillo, "a dado" o "a podio", cuadrangular y casi un altar, austero en su concepción, que encuentra su mejor paralelo en la Tumba de los Stronii, en el extremo suroeste de la necrópolis pompeyana de Porta Nocera, aun cuando cuenta con precedentes bien conocidos "etruscos, griegos, orientales y mediterráneos en general" (Pérez López 1999: 14, y 23 ss., figs. 17 y 18). De todos modos, su morfología no debió ser siempre la misma. Así, además del león tallado sobre la cubierta de una cista procedente de Carissa Aurelia (Pérez López 1999: 48 ss., $\left.\mathrm{n}^{\mathrm{o}} 10\right)$, destacan el caso de Urso, reconstruido como una torre decorada con un friso en relieve de venationes (Atencia y Beltrán 1989: 155 ss.), o el león de Salaria (Úbeda, Jaén), que sujeta una cabeza humana bajo su zarpa izquierda, interpretado como un prótomo de esquina (también la izquierda) de un monumento rematado por una edícula abierta, construido en torno al tercer cuarto del siglo I a.C. (Beltrán Fortes y Baena del Alcázar 1996: 50, fig. 17, A-B; Pérez López 1999: 24, y 116-117, no 43; Beltrán Fortes 2002: 238 ss.).

I. Pérez se decanta por atribuir estos monumentos a individuos venidos de Italia que habrían desempeñado cargos relevantes en los primeros momentos de la colonización de Hispania, descartando cualquier posible continuidad con modelos o costumbres de época prerromana (Pérez López 1999: 32); una idea que suscriben otros autores $^{37}$, para quienes su aparición relativamente frecuente en ciudades del Bajo Guadalquivir, donde no se documentan leones durante la etapa prerromana previa, estaría documentando un proceso de monumentalización funeraria sin precedentes a lo largo del siglo II a.C., vinculado a modelos romano-itálicos (Beltrán Fortes 2002: 238). Se dibujaría así un paisaje sepulcral en el que habría sido fácil distinguir el componente

36. Resultan, de hecho, especialmente frecuentes en ciertas zonas de Baetica donde estuvo muy presente el componente púnico; así, Astigi, Baelo Claudia, Cappa, Conobaria, Carissa Aurelia, Gades, Hasta Regia, Malaca, Nabrissa, Salaria, Salpensa, Ugia, Urso o la ya citada Carissa Aurelia.

37. "El león asociado a una cabeza humana protege a los descendientes del que ha fallecido, transporta al difunto al más allá, ensalza la virtus de una familia y evoca la etnia de una minorí, probablemente norditálica, que en Provenza, Cuenca, Albacete, Jaén, Córdoba o Sevilla encontró la muerte lejos de su pais" (Aranegui 2004: 225).

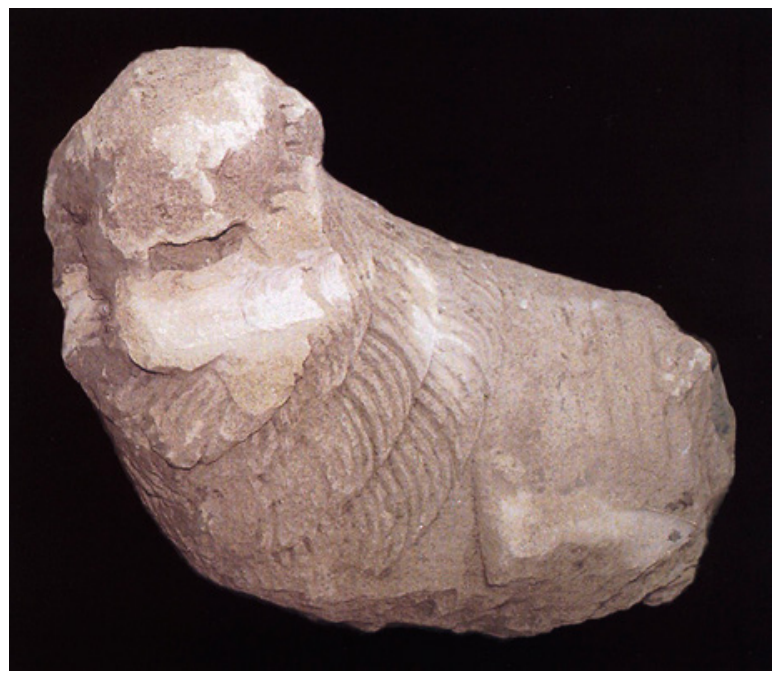

Figura 13. Carissa Aurelia. León funerario (Pérez López $\left.1999,53, \mathrm{~N}^{\circ} 10\right)$

foráneo del autóctono. Sin embargo, las cosas no siempre son tan sencillas, entre otras razones por el alto componente de emulación que los pueblos sometidos suelen desarrollar en relación con el pueblo dominante, empezando siempre por sus clases dirigentes. No sería extraño, por tanto, que algunas de ellas (todavía poderosas y con lógicas necesidades de autorrrepresentación) hubieran elegido tales monumentos como un método eficaz de integrarse en la cultura de la potencia invasora sin renunciar por completo a las formas arquitectónicas e iconografías funerarias que hasta entonces les habían servido como manifestación última de estatus y de poder, de la posición que ocuparon en vida, de su escatología y su actitud ante la muerte. Haría falta, pues, que la epigrafía fuera más explícita para resolver el problema e identificar de paso los matices que determinaron en cada caso la elección.

Entronca todo ello con el tema arduo y complejo de la llegada progresiva de tendencias artísticas y modelos a Hispania, quizá a través de talleres itinerantes, de simples cartones, o de corrientes multidireccionales que tendrían como puntos más importantes de entrada el nordeste y levante peninsulares, además, como es lógico, del sur, verdadero catalizador de las influencias venidas del centro y el Este del Mediterráneo (incluidas las grandes islas y la península itálica) y del norte de África, tan importante en la conformación del sustrato peninsular prerromano y objeto permanente de relación e intercambios, dadas su cercanía y su pujanza. Destaca, a este respecto, el papel realmente determinante ejercido desde primera hora por el caput provinciae, 


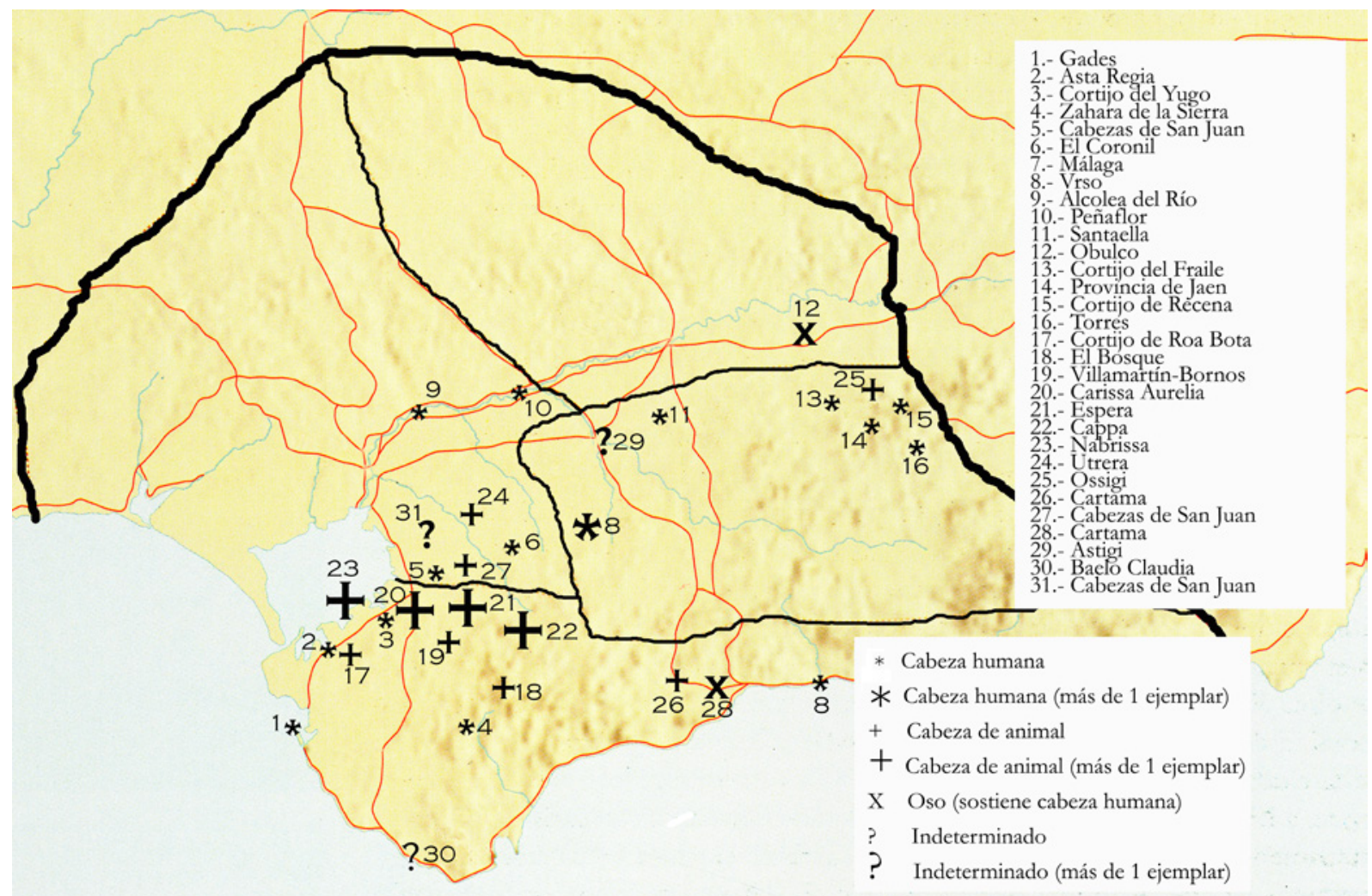

Figura 14. Dispersión de leones funerarios en la Bética (Vaquerizo 2010, Figura 268; elaboración S. Jurado).

como foco de atracción de las más importantes maestranzas, lugar preferido por las elites para desarrollar carrera y dejar testimonio público (también eterno, o cuando menos con vocación de eternidad) de su proyección social y poder adquisitivo, y centro irradiador de corrientes, materiales e influencias a otras muchas ciudades de la región. Quizá conviene recordar una vez más que Córdoba es la única ciudad de la Bética (al menos, según el estado actual de la investigación arqueológica) que documenta hoy por hoy, de manera paradigmática y sin cesuras, la misma evolución en el tiempo por lo que se refiere a ritos, topografía, monumentalidad, ornamentación estatuaria, materiales, formas arquitectónicas, ceremonias conmemorativas y expresiones del más variado tipo, del mundo funerario metropolitano (sobre el tema, vid. por ejemplo Zanker 2002; especialmente 60 ss.), con lo que esto representa desde el punto de vista cultural, ideológico, social, simbólico y, por supuesto, humano.

Esta adaptación por ambas partes a la realidad coyuntural y a las necesidades o disponibilidad del otro es la que favorece precisamente el carácter híbrido, o "bilingüe", tan característico en las producciones artísticas de los últimos siglos republicanos (Rodríguez Oliva 1996: 20 ss. $)^{38}$.

\section{b) Iconografía y tradiciones}

Juegos funerarios

R. Olmos, primero (Olmos 1998: 438), y M. Bendala, después (Bendala 2002c: 71 ss., y 2006), han querido relacionar el desarrollo de la gladiatura en Hispania con la costumbre típicamente hispana de la fides o devotio, conforme a la cual, y siguiendo parámetros helenísticos aprendidos inicialmente de los púnicos y más tarde de los propios romanos, los guerreros más cercanos a un princeps, rey, reyezuelo, régulo, aristós, o simplemente imperator (entendido como general victorioso), se inmolaban tras su muerte en combate mediante monomaquias para las que se ofrecían voluntarios, juramentados

38. Vid. el más reciente estudio de conjunto sobre esta problemática, así como las piezas que comentaré a continuación, en Noguera y Rodríguez Oliva (2008). 
para de ninguna manera sobrevivir a su jefe. Así lo recogen algunos autores antiguos en relación con los funerales del padre y del tío de Publio Cornelio Escipión (Livio, 28, 21; 29, 1), o de Viriato (Diodoro, 33, 21), y así habría quedado reflejado en monumentos tan importantes como el conjunto escultórico del Cerrillo Blanco de Porcuna, o los relieves de Osuna, donde parecen representarse también escenas de venationes, o por lo menos ajusticiamientos con fieras (Blázquez y Montero 1993: 73 ss.). En las paradas militares y combates sangrientos de carácter agónico que decoraron dichos monumentos se percibe una clara tendencia a la heroización de los jefes y soberanos (anterior sin duda a la celebración funeraria de los Escipiones en Carthago Nova, allá por 207 a.C.), que tal vez incluso, como defiende Bendala, se encuentra de manera remota en la base del posterior desarrollo del culto al Emperador.

\section{Culto a los ancestros}

A pesar de que, como he ido avanzando, multitud de trabajos han venido a demostrar en los últimos años la fuerte (y predominante) filiación itálica de buena parte de los monumentos funerarios documentados en Baetica, y muy en particular de la ornamentación escultórica que los acompaña, hasta ahora se había dado por sentado que esta norma encontraba su excepción en el caso de Baelo Claudia. Una apreciación que a la luz de las nuevas interpretaciones resulta, cuando menos, cuestionable (Vaquerizo 2006: 350 ss., y 2008a).

Muchas de las tumbas de la Necrópolis Sureste baelonense, de cremación y también de inhumación, incorporaron en su exterior (al menos, entre el segundo tercio del siglo I y el tercero del siglo II d. C.; Remesal 1979: 43; Jiménez Díez 2006) una o varias representaciones antropomorfas muy sumarias ${ }^{39}$ en piedra y bulto redondo (de entre todas ellas, sólo una claramente femenina; Paris et alii 1926: 108, fig. 65, 1) (Figura 15), cipos en forma de columna ${ }^{40}$, o simples betilos ${ }^{41}$, con

39. A lo largo del tiempo se han recuperado más de un centenar, hoy dispersas por diversos Museos y colecciones, o sencillamente desaparecidas. Su tosquedad no obedecería a limitaciones técnicas, sino al deseo expreso de remitir a modelos arcaizantes (Jiménez Díez 2006), y también, probablemente, a su estucado último, que permitiría detalles hoy perdidos.

40. Una actualización crítica de este tipo de remate funerario, de claro carácter anicónico, posible origen griego, y relacionado en ocasiones con el culto a Apolo, Venus o Dionisos, en Zampieri (2000, especialmente $48 \mathrm{ss}$.).

41. Éstos - cuya denominación como tal utilizo de forma genérica, sin entrar en cuestiones semánticas, morfológicas y estructurales

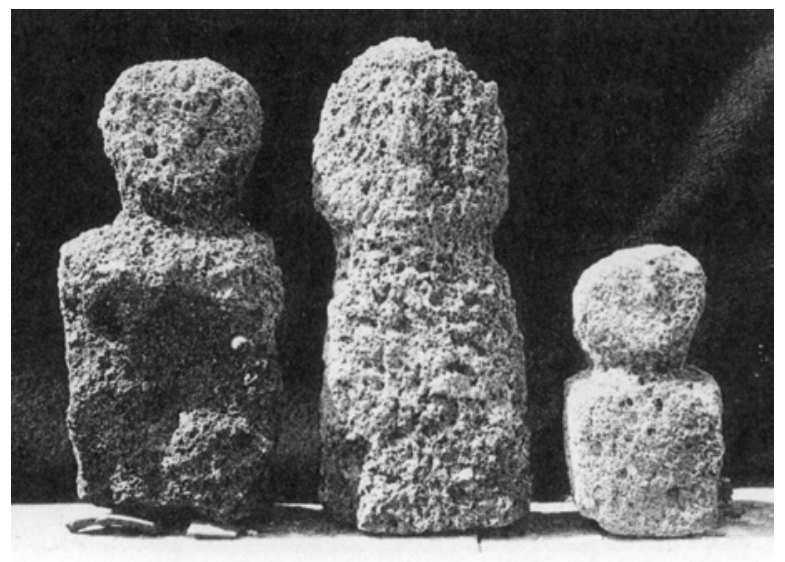

Figura 15. Baelo Claudia. Representaciones funerarias, entre las cuales una claramente femenina (izquierda) (Paris et alii, 1926, Pl. XVIIIA).

tamaños que oscilan de manera habitual entre $15 \mathrm{y}$ $40 \mathrm{~cm}$. Unas y otros, carentes de cualquier tipo de atributo que pudiera facilitar su identificación (al menos, en el estado en que nos han llegado), fueron colocados siempre en el lado sur o suroeste de las tumbas y monumentos, justo el que abre al mar, y mirando hacia él; algo a lo que se atribuye un claro, consciente y pretendido componente ritual, como al hecho de que fueran dispuestos semienterrados, frecuentemente en contacto directo con la propia olla ossuaria, o que junto a una misma tumba se depositaran hasta cuatro o cinco de estos elementos (Paris et alii 1926: 108-109). Pero quizá el aspecto más interesante de todos es la relación directa de la mayor parte de ellos con los tubos para profusiones y las mensae funerarias, lo que es lo mismo que decir con los banquetes y libaciones que acompañaban al sepelio, o las ceremonias conmemorativas en memoria y homenaje del difunto. De hecho, muchos aparecen rodeados de fragmentos de piezas cerámicas utilizadas a tal fin, rotas finalmente, tal vez incluso sobre las propias piedras, como llegó a sugerir G. Bonsor (Paris et alii 1926: 108). Un buen número de estos mismos enterramientos estaban presididos por su respectiva estela, que

que han sido bien analizadas recientemente por C. Rossignoli (1992) o I. Seco (2002 y 2010)- fueron interpretados en el momento de su aparición como una evolución de aquéllas, a las que sustituirían a partir de mediados del siglo II d.C. Acompañarían a las últimas cremaciones y, en opinión de G. Bonsor y P. Paris, se relacionarían con el culto a Tanit, como ocurre en otras necrópolis del norte de África (Paris et alii 1926, 113-114). Una hipótesis hoy descartada, puesto que en excavaciones posteriores (Remesal 1979) pudo comprobarse la coexistencia en el tiempo y en el espacio de tipologías muy diversas. 
sirvió de sema o señalización externa, lo que en tales casos podría haber privado a los "muñecos" de cualquier funcionalidad en este sentido (Jiménez Díez 2005: 171).

El que los bustos y betilos fueran dispuestos semienterrados podría obedecer, sin más, a una simple cuestión práctica (por ejemplo, evitar que se desplazaran de su ubicación, o que fueran robados...), pero también a criterios de inmanencia relacionados con su carácter liminal y "fronterizo" (Jiménez Díez 2006). El hecho de que en algunas tumbas aparezca un número de piezas muy superior al de individuos enterrados permite plantear la hipótesis de que tales expresiones pétreas fueran incorporadas al ritual funerario como ofrendas o regalos por parte de familiares y amigos, que contribuirían al funus potenciando la memoria del finado y quizás también su protección por parte de las más altas divinidades del panteón ${ }^{42}$. Conviene no olvidar, por otra parte, el carácter múltiple de los betilos ofrendados en algunos de los santuarios púnicos más importantes del Mediterráneo prerromano (Rossignoli 1992: 91).

A tenor de ejemplos similiares documentados en santuarios (Seco 1999 y 2010) o depósitos rituales (Bandera et alii 2004), los estiliformes, con base angular o circular y fuste truncado, parecen representar, conforme a parámetros bien tipificados de aniconismo, a la propia divinidad; pero, de nuevo, también al difunto, en el caso de las necrópolis griegas o tardoetruscas (como La Banditaccia, en Cerveteri, o Tarquinia), donde conviven en las mismas tumbas piedras estiliformes con exvotos antropomorfos, e incluso algunas de las primeras engrosan el remate de sus fustes hasta evocar una cabeza humana, personalizadas finalmente con el nombre del difunto grabado o pintado sobre la piedra (Steingräber 1991; Blumhofer 1993; Zampieri 2000: 48 ss.; Jiménez Díez 2006).

Estaríamos, por consiguiente, ante manifestaciones polisémicas y quizá polifuncionales -incluso polivalentes, y no necesariamente coincidentes entre sí en su significado último-, que evocaban la imagen del familiar desaparecido o las divinidades a quienes se confiaba su protección (en una simbiosis bastante llamativa que parece fundir al difunto con el dios), y tal vez incorporaron otros simbolismos de carácter conmemorativo, honorífico, de prestigio u homenaje, o simplemente votivo; siempre, relacionados directamente con formas romanas de entender el ritual y el culto a los muertos. Su filiación es difícil de determinar, supuesto su uso en

42. Tal vez romano, pero expresado todavía en un lenguaje simbólico de base púnica...; "híbrido", por tanto, como sugiere A. Jiménez Díez. muy diversos ambientes del Mediterráneo antiguo ${ }^{43}$, lo que podría abogar en beneficio de una poligénesis; sin embargo, lo más probable es que llegaran a Hispania desde el área centro-itálica (donde se habrían desarrollado inicialmente de la mano de los griegos, y después, o simultáneamente, de los etruscos), a través de colonos y comerciantes, cuyo activo papel en lugares como Barcino, y sobre todo Baelo, está fuera de toda duda. En esta última alcanzaron un particular desarrollo, de tintes claramente arcaizantes, por avenirse quizás a la perfección con criterios de tradición púnica. Esta idea no repugna en absoluto a la imagen de un Mediterráneo antiguo en progresiva homogeneización cultural, caldo de cultivo privilegiado para el triunfo inmediato y rotundo de Roma. Una Roma conformada a partir de mil y una influencias, que fue irradiando de acuerdo con el respectivo origen de sus colonos, pudiendo sin dificultad llegar a confluir varias de ellas en lugares tan cosmopolitas, abiertos, frecuentados y heterogéneos como Baelo Claudia, cuya población debió aglutinar desde primera hora a individuos de muy diversas procedencia geográfica, condición social y tradiciones culturales.

La posible identificación de los "muñecos" con el espíritu e incluso la imagen de los fallecidos fue sugerida ya, hace años, por M. Bendala, quien destacó su carácter anicónico, "de tradición semítica, la misma que impregna el conjunto de la necrópolis" (Bendala 1995: 284); y recientemente se ha pronunciado en el mismo sentido I. Seco, para quien el "retrato funerario fue probablemente el sentido primordial de las piezas" (Seco 2002: Aptdo. II.4.3, y 2010: 367 ss.). Retratos con una fuerte concesión al aniconismo de posible componente norteafricano en cuanto a estilo y ejecución material, pero similares en concepto a otras manifestaciones similares en área itálica, como las estelas y retratos documentados en algunas necrópolis del golfo de Nápoles (De'Spagnolis 2001: 176), caso de Pompeya (D'Ambrosio, De Caro y Vlad 1983: 7 ss.; Kockel 1987: Tafs. 29 y 30; D’Ambrosio y De Caro 1987: Taf. 31-39) o Nuceria Alfaterna (actual Nocera Superior) (De'Spagnolis 2001: 173 ss., figs. 5 ss.) $)^{44}$.

43. Incluidas las ciudades de Benevento y Tarento, donde algunos bustos funerarios, carentes en su mayor parte de contexto arqueológico, ofrecen una gran similitud con los baelonenses (Rodríguez Oliva 2002: 279; Jiménez Díez 2006)

44. Las denominadas columelle, que se consideran una contaminación derivada de los hermas-retrato, se limitan básicamente al territorio de la antigua confederación nocerina, con muy pocos ejemplos fuera del área campana, atribuidos sin excepción a gentes procedentes de esta región. Fueron utilizadas en un arco cronológico que 
Piezas prácticamente idénticas a las baelonenses se constatan también entre las estelas púnicas sardas y de Selinunte, dispuestas junto a la vía funeraria que conectaba con el santuario de Zeus Meilichios, dios infernal que protegía el fuego del hogar y la familia (como después lo harán Manes, Lares y Penates), contiguo al de Deméter Malophoros, siempre en Sicilia. Cronológicamente se sitúan entre los siglos IV y I a.C. y se consideran púnicas "di stile popolaresco", con una fuerte componente local (Tore 1975; Moscati 1988: 314-315, y 1995: Vol. I, 394-399, y vol. II: 530-541). Por otra parte, la asociación de cupa structilis, mensa libatoria y betilo apoyado en uno de los lados cortos de la tumba se observa en necrópolis norteafricanas como las de Henchir-Zoura, o Puerta de Cesarea, en Tipasa ( $C f r$. Julià 1965: 50 ss.), que ofrecen un enorme paralelismo con la de Baelo (Jiménez Díez 2006); sin que falten incluso en alguna de las hispanas: es el caso de la excavada bajo la Plaza de la Vila de Madrid, en Barcino, una de cuyas cupae apareció dotada de canal libatorio y mensa adosada a su cara principal y flanqueada por varios betilos (simples piedras de tendencia cúbica) (Durán y Sanpere 1963: 92, Sep. no 69; Bonneville 1981: $15 \mathrm{ss}^{45}$ ). Finalmente, betilos asociados a tumbas han sido señalados también en la necrópolis romana de $G a$ des (Bendala 1995: 284; Cfr. Romero de Torres 1934: 90-91, láms. XLIX-L).

Se trataría, en definitiva, de evocaciones quizá "de carácter genérico e indiferenciado" en algunos casos, como quiere A. Jiménez Díez ${ }^{46}$, pero personalizadas como retratos o evocaciones individuales y específicas del fallecido en otros muchos, por lo menos los antropomorfos. Estucado, policromía e inscripciones pintadas pudieron haber estado presentes en los bustos y betilos de Baelo, como se comprueba, por ejemplo, en numerosos cipos y estelas funerarias de Gades

abarca entre el siglo II a.C. y la segunda mitad del siglo I d.C., pero en algún caso perduran en los primeros años del siglo II d.C. Pudieron tener precedentes lígneos, y no se descarta que en su parte anterior estuvieran pintadas, evocando los rasgos del difunto. Se atribuyen a una tradición de origen local (De'Spagnolis 2001: 176-177).

45. Una revisión en profundidad de la topografía funeraria, las formas sepulcrales y los ritos documentados en esta necrópolis, reexcavada recientemente, puede consultarse en varios artículos que abren el número 3 de la revista Quaderns d'Arqueologia i Història de la Ciutat de Barcelona (QUARHIS), en particular Beltrán de Heredia (2007).

46. Elementos rituales de carácter arcaizante propios de un culto local, que mezclarían la tradición itálica (con referentes incluso al mundo etrusco) y norteafricana; objetos cultuales en sí mismos y elemento de referencia a la hora de realizar las profusiones en las festividades conmemorativas, sirviendo al tiempo para homenajear al fallecido y como intermediarios con la divinidad y el mundo de ultratumba.

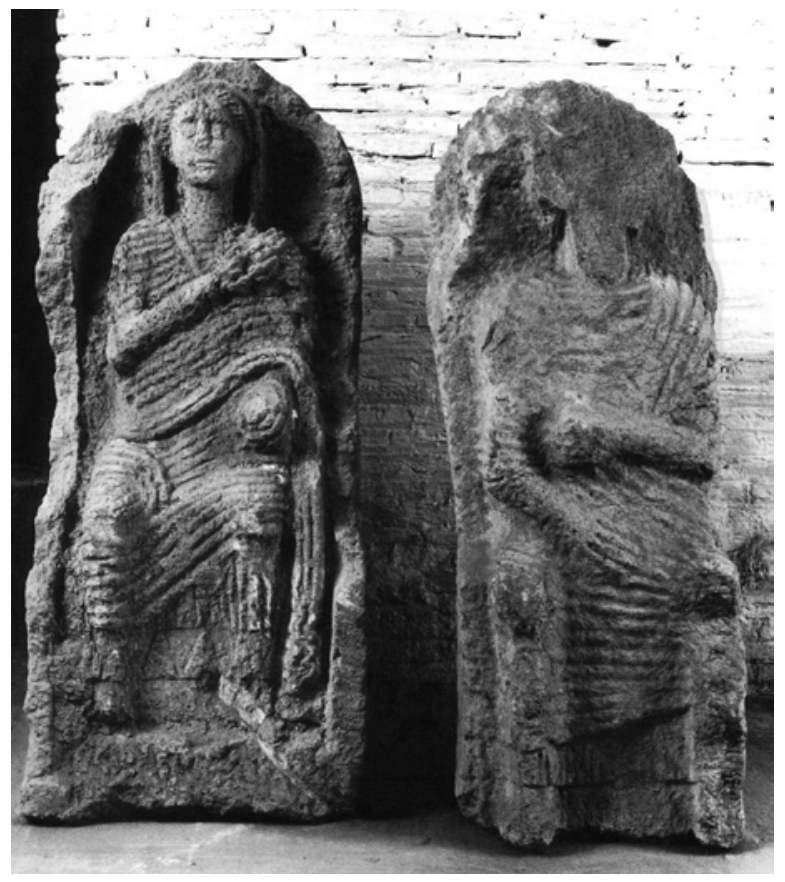

Figura 16. Conobaria (Alcalá del Río, Sevilla). Damas sedentes, concebidas como estatuas funerarias (Noguera, Rodríguez Oliva 2008, Figura 39)

(Gener 1999: 16; López de la Orden 1995: 19, Inscripciones números 145, 250, o 253, o lám. XXVI). De ser así, su aspecto original habría tenido poco que ver con el que nos ha llegado, privado de detalles de enorme importancia para entender en toda su dimensión la forma, el uso y la interpretación de tales manifestaciones arqueológicas. Abunda en esta idea la identificación clara de al menos uno de los casos conocidos como individuo de sexo femenino y la insinuación del brazo derecho plegado sobre el pecho (que no se da en el mundo púnico antes de su romanización), a la manera de las estatuas funerarias romanas de cronología tardorrepublicana y altoimperial (Figura 16), en dos de los ejemplares conservados en el Museo Arqueológico Nacional de Madrid (MAN 33181 26/15/988 y MAN 33182 26/15/989; Seco 2002). Desde este misma óptica, no encuentro ningún problema en que sirvieran además, ocasionalmente, como marcadores de las tumbas, y que su orientación hacia el mar, al que dan vista, reflejen de forma polisémica la mirada nostálgica de quienes representan hacia el que fue su hábitat más preciado, su principal medio de vida, su vía de acceso a la ciudad, la frontera con el mundo de los bienventurados, a la manera griega, o, tal vez, la morada de su/s más importante/s divinidad/es protectora/s. 


\section{C) El ritual}

\section{Coexistencia de cremación e inhumación}

Estos últimos años he podido comprobar de forma fehaciente que, como ocurre en otros lugares de Hispania, cremación e inhumación conviven en las necrópolis de la Bética desde el mismo momento en que se constatan los primeros enterramientos romanos (Vaquerizo 2006, 2007 y 2010: 282 ss., Fig. 264) (Figura 17). En principio, parece claro que las razones de tal coexistencia varían en función del sustrato cultural de cada una de las ciudades y la composición étnica de los aportes coloniales llegados desde Italia. Así, en Gades, Malaca, Baelo Claudia o Carissa Aurelia el rito inhumatorio sería, en principio, una perduración de viejas prácticas de tradición púnica, mientras en centros urbanos como Corduba las primeras inhumaciones corresponderían, supuestamente, a gentes itálicas (colonos, militares, comerciantes), o quizá orientales (libertos, esclavos). Como en la Cispadana (Ortalli 2001: 217-218, y 222 ss.), tales individuos utilizarían este rito como un elemento definitorio de cultura o tradición familiar. Tampoco podemos sin descartar que pudieran corresponder a individuos de filiación semita, cuya presencia en la ciudad parece suficientemente probada (vid. supra). No obstante, como en tantos otros aspectos relacionados con el mundo funerario la realidad es mucho más compleja de lo que cabría suponer y dista mucho de admitir categorizaciones. Es preciso, pues, seguir trabajando en el tema, desde una posición de flexibilidad mental que evite apriorismos innecesarios como los que hasta hace poco rebajaban de forma automática la cronología para cualquier enterramiento de inhumación con independencia de otros criterios materiales o incluso estratigráficos.

\section{Banquetes y depósitos rituales}

Destaca, finalmente, la problemática planteada por los depósitos rituales. Los mejor estudiados son, sin lugar a dudas, los gaditanos de épocas púnica y romana (Niveau 2010, con bibliografía anterior), pero como en tantos otros aspectos del mundo funerario es posible que no hayamos sabido mirar, porque elementos similares (aun cuando ello no implique identidad total) comienzan también a observarse en otros lugares como $\mathrm{Urso}^{47}$,

47. Referencia de R. Corzo $(1977,23)$ a un "silo" de enormes proporciones en la zona de las canteras, repleto de huesos (no se
Lora de Estepa ${ }^{48}$ o Carmo, en este último caso con un cierto protagonismo de betilos e inhumación de cánidos (Román Rodríguez 2001; Román Rodríguez y Conlin 2005; Román Rodríguez y Vázquez 2005, $a$ y $b$; Vaquerizo 2010a: $252 \mathrm{ss}$.) que podrían inclinar la balanza en favor de un componente más litúrgico o ctónico que estrictamente funerario ${ }^{49}$. Son ejemplos que recuerdan de cerca al documentado en la barcinonense Plaza de la Vila de Madrid (Beltrán de Heredia 2007): un pozo de agua reaprovechado, en cuya excavación se observaron al menos dos fases (el relleno no pudo ser agotado por motivos de seguridad), y a algunos otros más antiguos, como los del Tossal de les Basses, en Alicante, con una profundidad de 10 y 12 metros, en los que fueron enterrados perros y caballos alternados con algunos hombres, mujeres y niños, en ocasiones depuestos con cierta ritualidad y otras dejados caer de cualquier manera (AAVV 2007: 62-65).

Estos pozos y fosas tendrían que ver con prácticas rituales en las que ocuparían un papel determinante los banquetes, $y$, como antes adelantaba, están siendo objeto de atención preferente en Cádiz, donde incluyen cerámicas de todo tipo (también, y en buen número, la consabida terra sigillata, hasta ahora poco conocida en los ambientes funerarios de la Gades romana), ánforas, lucernas, vidrios, hueso, restos malacológicos y de pescado, terracotas, monedas, agujas, alfileres, anzuelos, pesas de plomo para redes, armas... En algunos, como los de Ciudad de la Justicia (Sibón, Gómez y Niveau 2007), no se

especifica si humanos o de animal) y cerámica, entre la que pudieron ser reconstruidas algunas urnas cinerarias.

48. Pozo circular construido íntegramente en sillería, con 2,60 m de diámetro interior y $6,60 \mathrm{~m}$. de profundidad, en cuyo interior fueron recuperados numerosos carbones, restos de animales, ollitas cerámicas llenas de ceniza, un ara de piedra y alrededor de treinta lucernas de los siglos IV y V d.C., por lo que parece que su última utilización habría tenido lugar en esta época (aun cuando los tres metros de potencia de sus rellenos constatarían un uso mucho más dilatado en el tiempo). Se encuentra a unos quince metros de un área de necrópolis, e inmediato a una estructura monumental de funcionalidad desconocida que presenta la misma técnica constructiva, pero sus excavadores no han llegado a establecer la relación exacta entre los diversos elementos, ni tampoco su diacronía (Guerrero, Juárez 1990, 316 ss.)

49. El papel de los perros en el ritual funerario ha sido objeto reciente de estudio en relación con el mundo púnico (Niveau y Ferrer 2004; Niveau 2008), griego, etrusco, itálico y romano (Beltrán de Heredia 2007; Lacam 2009). La presencia de cánidos en tumbas romanas (inhumados con el difunto, o sacrificados durante las ceremonias asociadas a su sepelio) es bastante frecuente. Así se documenta por ejemplo en Fidene, donde aparecieron ocho esqueletos de estos animales en relación con las tumbas 15, perteneciente a una mujer adulta, y 29, de un adolescente (De Filippis 2001: 65, fig. 6; De Grossi 2001), o en Rímini: un pequeño perro enterrado en una caja de madera, con un ungüentario como ajuar, en medio de un área funeraria (sepulcretum de la via Flaminia) de época pleno imperial (Ortalli 2001: 239, fig. 22). 


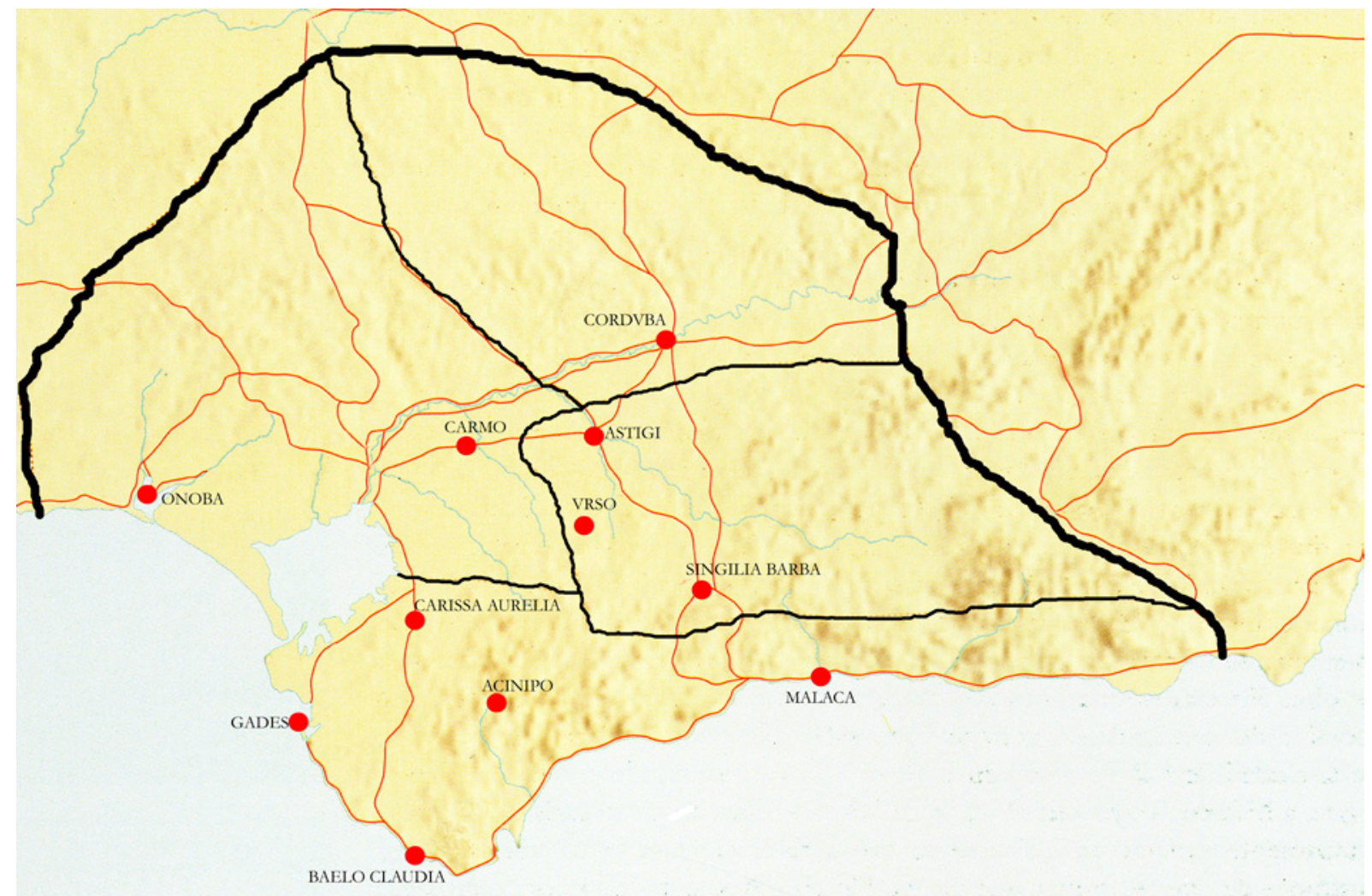

Figura 17. Principales conjuntos urbanos de la Bética en los que crematio y humatio coexisten desde fechas altas (elaboración S. Jurado).

han detectado restos de animales sacrificados, por lo que sus excavadores dudan entre considerarlas restos de silicernia, o bien depósitos secundarios de ajuares amortizados tras desplazarlos por algún motivo indeterminado de su ubicación original (verbigracia, como resultado de la limpieza periódica de la necrópolis). V. Gómez (Gómez Fernández 2007) los entiende como una prolongación cultural, una perduración -incluso intensificación- de costumbres anteriores en una sociedad romana con fuerte tendencia al mestizaje (como mestiza y cosmopolita era ya, desde siempre, la propia población gadeirita); algo que parece bastante razonable, si hemos de juzgar por el uso prolongado de algunos de ellos y la cronología relativamente tardía de buena parte de la numismática recuperada en su interior (Arévalo 2009 y 2010).

\section{UN TEMA ABIERTO}

Aun cuando existe en todas ellas un trasfondo común que en cierta medida puede fusionarse con el concepto que tradicionalmente se ha venido identificando como romanización, lo cierto es que las ciudades hispano-béticas ofrecen bastantes singularidades en cuanto a su forma de abordar la muerte, la planificación y crecimiento de sus áreas funerarias, el ritual o las formas arquitectónicas elegidas, los ajuares o las ceremonias conmemorativas, la coexistencia de cremación e inhumación, o la introducción más tardía de esta última, la cristianización de su topografía funeraria y el tránsito a la Antigüedad Tardía.

Las diferencias iniciales entre ellas vienen dadas por la existencia de una tradición local diferente. Así ocurre con el componente púnico, que tanto ha dado que hablar en los últimos años, especialmente a partir de los trabajos de M. Bendala, pionero en estos temas y definidor en buena medida del hibridismo cultural de componente norteafricano en la Hispania romana, presente en determinadas manifestaciones funerarias de una gran parte de la Bética, donde perdura hasta bien avanzado el Imperio. Apenas ha dejado huella en la epigrafía, por lo que observarlo es a veces cuestión de sutileza (cámaras hipogeicas, cierres pétreos, ollae ossuariae de tradición indígena o púnica, banquetes 


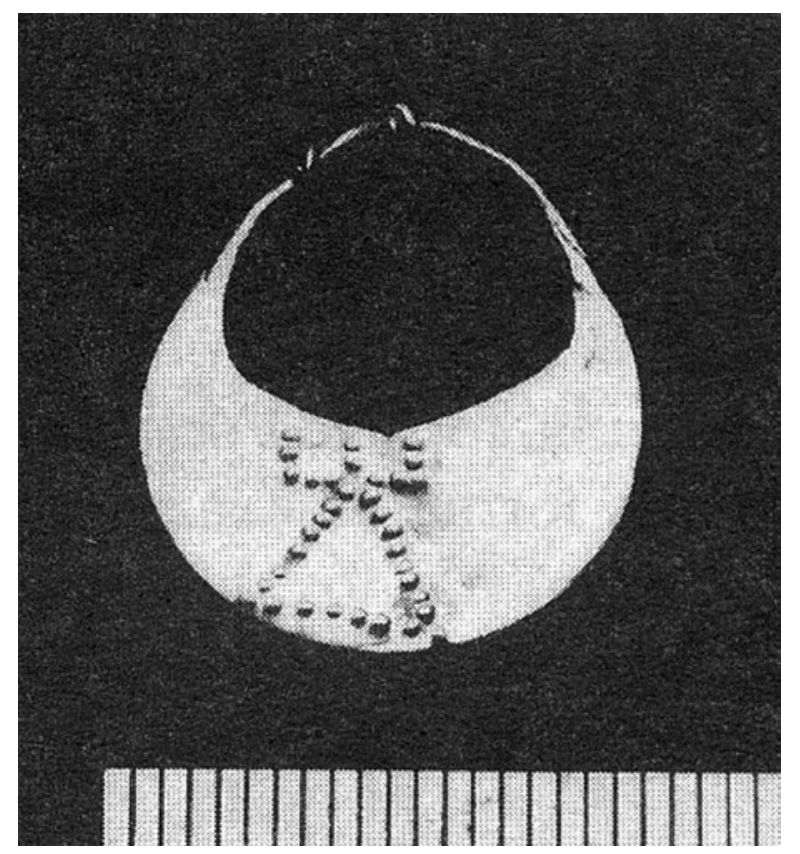

Figura 18. Orippo (Dos Hermanas). Pendiente en forma de media luna con el símbolo de Tanit (Martín Ripoll, Martínez 1995, Foto 4).

conmemorativos, pozos y fosas rituales, liturgias y escatología singulares, etc.), mientras en otras ocasiones se hace explícito. Es el caso, por ejemplo, del pendiente de oro en forma de media luna con la representación de Tanit recuperado entre el ajuar de una tumba de Orippo (Dos Hermanas, Sevilla), fechado supuestamente en el siglo II d.C. (Martín Ripio y Martínez 1995: 688 ss.; Martínez Peñarroya 1997) (Figura 18). Destaca en este mismo sentido el uso simultáneo de cremación e inhumación que se observa en la mayor parte de los conjuntos urbanos béticos desde, incluso, el siglo II a.C., favorecido sin duda por la llegada de gentes del centro o sur de Italia, que venían inhumando desde siglos atrás y trasladaron con ellos sus particulares hábitos funerarios (Vaquerizo 2005), pero también por las prácticas funerarias indígenas, de componente fundamentalmente púnico, entre las que el rito inhumatorio desempeñó un papel de gran trascendencia.

Sólo Baelo Claudia y Corduba han proporcionado hasta la fecha necrópolis en las que podemos rastrear los mismos procesos detectables en el mundo funerario romano más ortodoxo, que también en ellas evoluciona desde los puntos de vista ritual y morfológico hasta el final del Imperio, marcando todas las etapas del mismo. La monumentalización de estas necrópolis urbanas parece probada a partir de mediados del siglo I a.C., muy especialmente de su último cuarto, en directa relación con los comienzos de la etapa augustea y los procesos de urbanización, convertida en barómetro privilegiado del nivel de integración en la cultura romana por parte de las elites locales. Sin embargo, a día de hoy no parece existir duda sobre la existencia de un importante componente monumental más antiguo en zonas de tradición previa, donde es muy posible que en los primeros tiempos se confundieran los influjos: mediterráneos, helenísticos, púnicos e itálicos, en diferente grado y de la mano de colonos de procedencia diversa y de las aristocracias indígenas. Presumiblemente, éstas habrían establecido con Roma relaciones de clientela o subordinación más formal, impuesta o admirativa que real, traduciéndolas en rituales de gran boato (recordemos, por ejemplo, los funerales de Escipión, en Cartagena, o de Viriato, en Lusitania) y tumbas monumentales con los que expresaban fórmulas ideológicas de base común a través de claves estéticas autóctonas. Sería el caso de Osuna y Estepa, cuyos relieves funerarios más viejos remiten al siglo II a.C. (vid. como recopilación bibliográfica más reciente, Pachón, Ruiz 2006); igual que ocurre posiblemente con algunos de los leones estudiados por I. Pérez (1999) y diversas expresiones escultóricas (Noguera y Rodríguez Oliva 2008).

El problema es que, por el momento, ninguno de los restos atribuibles a estas etapas de contacto ${ }^{50}$ ha sido bien excavado ni convenientemente contextualizado, por lo que seguimos sin poder matizar nada en cuanto a la ubicación, la topografía, la densidad o los aspectos rituales de estas primeras necrópolis, sepultadas en ocasiones bajo las ampliaciones sucesivas de las propias ciudades, destruidas a lo largo del tiempo (quizá incluso en la misma época), o afectadas por alguna problemática que nos impide acabar de reconocerlas ${ }^{51}$.

Del mismo modo, por el momento no hay pruebas concluyentes que permitan asociar, de forma global y generalizada, los elementos funerarios hispanobéticos considerados tradicionalmente de filiación norteafricana con personas procedentes o relacionadas con el norte de África (quizás porque ya estaban aquí); lo que

50. Recordemos la discusión en torno al supuesto ritual funerario de origen atlántico que no dejaba huella arqueológica, imperante según algunos investigadores en el suroeste peninsular hasta la implantación del funus más característicamente romano, de fuerte base mediterránea (Ruiz Gálvez 1995; Escacena 2000).

51. Se trata, en cualquier caso, de un problema de intensidad o calidad investigadora, así como de buena o mala fortuna en la conservación de los restos, por lo que no cabe descartar que en los próximos años nuevas intervenciones, o la revisión en profundidad de las ya practicadas, deparen importantes sorpresas a este respecto. 
tampoco evita que tuvieran entre ellas un éxito especial. El mundo funerario romano fue lo suficientemente complejo y rico en sus expresiones rituales y formales como para admitir todo tipo de peculiaridades regionales y locales (también personales); como en realidad ocurrió en los más variados ámbitos de la vida. Y a ellas se sumaron las derivadas de la condición social, la necesidad de expresar públicamente la adscripción a una determinada cultura o identidad (sobre todo, por parte de aquéllos que querían dejar constancia expresa de su cercanía al nuevo poder dominante, o reivindicar, con mayor o menor sutileza, su etnicidad) y la capacidad adquisitiva: verdadero, último, condicionante de la inversión destinada a la última morada. De ahí que debamos ser especialmente cautos, manteniendo, a pesar de los avances indudables de estos últimos años y las aportaciones al respecto del homenajeado, el tema abierto.

\section{BIBLIOGRAFÍA}

AAVV (2007): El yacimiento arqueológico Tossal de les Basses. Seis mil años de historia de Alicante. Alicante.

ALFÖLDY, G. (1998): “La cultura epigráfica de la Hispania romana: inscripciones, auto-representación y orden social", en Hispania. El legado de Roma: 289-302. Zaragoza.

- (2001): "La sociedad del municipio de Carmo", a A. Caballos (ed.), Carmona Romana. Actas del II Congreso de Historia de Carmona: 339-362. Sevilla.

ALMAGRO GORBEA, M.J. (1984): La necrópolis de Baria (Almería). Campañas 1975-1978. Excavaciones Arqueológicas en España 129. Madrid.

ALVAR, J. (2007): "Fantasía y realidad, Cibeles en Carmona. Problemas historiográficos de un monumento funerario", Arys 5.200287-98. Huelva.

AMORES, F. (2001): "Entre campo y ciudad. La periferia urbana en Carmo", en A. Caballos (ed.), Carmona romana: 447-463. Carmona.

ANGLADA, R. y CONLIN, E. (2001a): "Excavaciones de urgencia en la calle Real 39 de Carmona: el baptisterio y el cementerio de época visigoda", $A A A^{\prime} 1998$ Vol. III.2933-942. Sevilla.

- (2001b): "Vigilancia arqueológica durante la remodelación del Paseo del Estatuto de Carmona (Sevilla): la fuente romana", $A A A^{\prime} 1998$, Vol. III.2: 944-948.

- (2003a): "Excavaciones de urgencia en la calle de Enmedio no 19 de Carmona (Sevilla): nuevos datos sobre la necrópolis romana", $A A A^{\prime} 2000$, Vol. III.2: 1203-1217.
- (2003b): "Intervención de urgencia en el Paseo del Estatuto, Carmona (Sevilla): el mausoleo romano", AAA'2000, Vol. III.2: 1218-1227.

ARANEGUI, C. (2004): "Leones funerarios de época iberorromana. La serie asociada a cabezas humanas”, en T. Nogales y J. Gonçalves (eds.), Actas de la IV Reunión sobre escultura romana en Hispania: 213-227. Madrid.

ARÉVALO, A. (2009): "La moneda en el ámbito funerario y ritual de la necrópolis de Cádiz: los hallazgos en pozos", en A. Arévalo (ed.), XIII Congreso Nacional de Numismática. "Moneda y Arqueología” (Cádiz 22-24 de octubre de 2007), voñl. I: 197-216. Cádiz.

- (2010): "Monedas para el Más Allá. Un primer acercamiento desde la Necrópolis de Cádiz”, en A.M. Niveau de Villedary y V. Gómez (coords.), Las necrópolis de Cádiz. Apuntes de arqueología gaditana en homenaje a J.F. Sibón Olano: 507-527. Cádiz.

ATENCIA, R. y BELTRÁN, J. (1989): "Nuevos fragmentos escultóricos tardorrepublicanos de Urso", en J. González (ed.), Estudios sobre Urso. Colonia Genetiva Iulia: 155-167. Sevilla.

BAENA DEL ALCÁZAR, L. y BELTRÁN, J. (2002): Las esculturas romanas de la provincia de Jaén. Murcia.

BANDERA, M.L. et alii (2004): "Nuevas evidencias de cultos betílicos en Turdetania", en J. Fernández Jurado, C. García y P. Rufete (coords.), Actas del III Congreso Español de Antiguo Oriente Próximo. Huelva Arqueológica 20: 239-255. Huelva.

BARATTA, G. (2006): “Alcune osservazioni sulla genesi e la diffusione delle cupae", L'Africa romana XVI: 1669-1682. Roma.

BELÉN, M. (1982): "Tumbas prerromanas de incineración en la necrópolis de Carmona", a Homenaje a C. Fernández-Chicarro: 269-285. Madrid.

- (1983): “Aportaciones al conocimiento de los rituales funerarios en la necrópolis romana de Carmona", en Homenaje al Prof. Martín Almagro Basch: 209-226. Madrid.

BELÉN, M. y LINEROS, R. (2001): “15 años de arqueología en Carmona", en A. Caballos (ed.), Actas del II Congreso de Historia de Carmona. Carmona Romana: 109-133. Carmona.

BELÉN, M.; CONLIN, E. y ANGLADA, R. (2001): "Cultos betílicos en Carmona romana", Arys. Antigüedad: Religiones y Sociedades 4: 141-163. Huelva.

BELÉN, M.; LINEROS, R. y PUYA, M. (1987): "Excavaciones en la necrópolis de Carmona", $A A A$ '1985: 417-423. Sevilla. 
BELÉN, M. et alii (1986): "Rituals funeraris a la necrópolis romana de Carmona (Sevilla)", Cota Zero. Revista d'Arqueologia i Ciencia 2: 53-61. Barcelona.

BELÉN, M. et alii (1997): Arqueología en Carmona (Sevilla). Excavaciones en la Casa-Palacio del Marqués de Saltillo. Colección Arqueología, Sevilla.

BELTRÁN DE HEREDIA, J. (2007): "La via sepulchralis de la Plaza Vila de Madrid. Un ejemplo del ritual funerario durante el Alto Imperio en la necrópolis occidental de Barcino", Quaderns d'Arqueologia i Història de la ciutat de Barcelona 3: 12-63. Barcelona.

BELTRÁN FORTES, J. (2002): "La arquitectura funeraria en la Hispania meridional durante los siglos II a.C.-I d.C.”, en D. Vaquerizo (ed.), Espacio y usos funerarios en el Occidente romano, vol. I: 293-328. Córdoba.

- (2008a): "Cultos orientales en la Baetica romana. Del Coleccionismo a la Arqueología”, en B. Palma Venetucci (ed.), Culti orientali. Tra scavo e collezionismo: 218-272. Roma.

- (2008b): "Esculturas romanas de Conobaria (Las Cabezas de San Juan) y Vrso (Osuna). La adopción del mármol en los programas estatuarios de dos ciudades de la Baetica", en J.M. Noguera y J.M. Conde (eds.), Escultura romana en Hispania V: 501-545. Murcia.

BELTRÁN FORTES, J. y BAENA, L. (1996): Arquitectura funeraria romana de la Colonia Salaria (Ubeda, Jaén). Ensayo de sistematización de los monumentos funerarios altoimperiales del alto Guadalquivir. Sevilla.

BENDALA, M. (1976): La necrópolis de Carmona. Sevilla, 2 vols.

- (1981): "La etapa final de la cultura ibero-turdetana y el impacto romanizador", en La Baja Época de la Cultura Ibérica: 33-48. Madrid.

- (1982), "La perduración púnica en los tiempos romanos. El caso de Carmona", Huelva Arqueológica 6: 193-203.

- (1990): "Comentario al artículo de A.T. Fear 'Cybele and Carmona: a reassessment'", AEspA 63: 109-114.

- (1995): "Necrópolis y ritual funerario en la Hispania Altoimperial", en R. Fábregas, F. Pérez y C. Hernández (eds.), Arqueoloxia da Morte na Península Ibérica desde as Orixes ata o Medievo: $277-$ 290. Santiago de Compostela.

- (2001): "La Carmona Bárquida", en A. Caballos (ed.), Carmona Romana: 37-51. Carmona.

- (2002a): "Estructura urbana y modelos urbanísticos en la Hispania antigua: continuidad y renovación con la conquista romana", Zephyrus 53-54, 20002001: 413-432.

- (2002b), "Perduraciones y romanización en Hispania a la luz de la arqueología funeraria: notas para una discusión", AEspA 75, Madrid, pp. 137-158.

- (2002c): “Virtus y pietas en los monumentos funerarios de la Hispania romana", en D. Vaquerizo (ed.), Espacio y usos funerarios en el Occidente Romano, Vol. I: 67-86. Córdoba.

- (2006a): “Hispania y la 'Romanización'. Una metáfora: ¿crema o menestra de verduras?, Zephyrus 59: 289-292.

- (2006b): "Expresiones y formas del poder en la Hispania ibérica y púnica en la coyuntura helenística", Pallas. Revue d'études antiques 70: L'hellénisation en Méditerranée occidentale au temps des guerres puniques (260-180 av. J.-C.) : 187-206. Mirail.

BERCIU, I. y WOLSKI, W. (1970) : «Un noveau type de tombe mis au jour à Apulum et le problème à voûte de l'Empire romain», Latomus 29: 919-965.

BERNAL, D. y LAGÓSTENA, J. (2010): "Muriendo en Gades en la Antigüedad Tardía”, en A.M. Niveau de Villedary y V. Gómez (coords.), Las necrópolis de Cádiz. Apuntes de arqueología gaditana en homenaje a J.F. Sibón Olano: 407-444. Cádiz.

BLÁZQUEZ, J.M. y MONTERO, S. (1993): "Ritual funerario y status social: los combates gladiatorios prerromanos en la Península Ibérica", Veleia 10: 71-84.

BLUMHOFER, M. (1993): Etruskische Cippi. Untersuchungen am Beispiel von Cerveteri. Colonia.

BONNEVILLE, J.-N. (1981) : "Les cupae de Barcelone : les origines du type monumental", $M C V$ XVII : 5-38.

CABALLOS, A. (1994): "Varia funeraria italicense", Habis 25: 225-245.

- (ed.) (2001): Carmona Romana. Actas del II Congreso de Historia de Carmona. Sevilla.

CALZA, G. (1940): La necropoli del Porto di Roma nell'Isola Sacra. Roma.

CARDENETE, R. et alii (1991): "Excavaciones en la calle Enmedio. Carmona (Sevilla)", AAA'1989, Vol. III: $575-580$.

COBOS, L.M. (1999): “Intervención arqueológica en el solar del Teatro Andalucía (Cádiz)”, $A A A$ '1995, Vol. III: 19-31.

CORRALES, P. y MORA, B. (2005): “Las prácticas funerarias", en Historia de la provincial de Málaga. De la Roma Republicana a la Antigüedad Tardía: 119-133. Málaga.

CORZO, R. (1977): Osuna de Pompeyo a César. Excavaciones en la muralla republicana. Sevilla. 
- (1992): “Topografía y ritual en la necrópolis de Cádiz", Spal 1: 263-292. http://dx.doi.org/10.12795/ spal.1992.i1.13

D'AMBROSIO, A. y DE CARO, St. (1987), "La necropoli di Porta Nocera. Campagna di scavo 1983", en H. von Hersberg y P. Zanker (eds.), Römische Gräberstrassen. Selbstdarstellung - Status - Standard: 199-228, Taf. 31-39. München.

D’AMBROSIO, A.; DE CARO, St. y VLAD, L. (1983): Un impegno per Pompei. Milano.

DE'SPAGNOLIS, M. (2001): "Costumi funerari nella necropoli monumentale romana di Pizzone a Nocera Superiore", en M. Heinzelmann et alii (eds.), Culto dei morti e costumi funerari romani. Roma, Italia settentrionale e province nord-occidentali dalla tarda Repubblica all'età imperiale, Internationales Kolloquium, Rom 1.-3. April 1998: 169-177. Deutsches Archäologisches Institut Rom, Wiesbaden.

DE FILIPPIS, M. (2001): "Riti particolari in un sepolcreto a Fidene", en M. Heinzelmann et alii (eds.), Culto dei morti e costumi funerari romani. Roma, Italia settentrionale e province nord-occidentali dalla tarda Repubblica all'età imperiale, Internationales Kolloquium, Rom 1.-3. April 1998: 63-65. Deutsches Archäologisches Institut Rom, Wiesbaden.

DE GROSSI, J. (2001): "L'uso dei cani nei riti funerari. Il caso della necropoli di età imperiale a Fidene. Via Radicofani", en M. Heinzelmann et alii (eds.), Culto dei morti e costumi funerari romani. Roma, Italia settentrionale e province nord-occidentali dalla tarda Repubblica all'età imperiale, Internationales Kolloquium, Rom 1.-3. April 1998: 77-82. Deutsches Archäologisches Institut Rom, Wiesbaden.

DÍAZ ARIÑO, B. (2008): Epigrafia latina republicana de Hispania. Instrumenta 26. Barcelona.

DURÁN Y SANPERE, A. (1963): "Una vía sepulcral romana en Barcelona", Cuadernos de Arqueología e Historia de la Ciudad 4: 61-103. Barcelona.

ESCACENA, J.L. (2000): La arqueología protohistórica del sur de la Península Ibérica. Historia de un río revuelto. Madrid.

- (2001): "Podando a Carmo. Perfiles del sustrato turdetano", en A. Caballos (ed.), Carmona Romana: 21-35. Carmona.

FEAR, A.T. (1990): "Cybele and Carmona: a reassessment", AEspA 63: 95-108.

FERNÁNDEZ FLORES, Á. y RODRÍGUEZ, A. (2007): "Vida y muerte en la Ilipa tartésica", en E. Ferrer et alii (eds.), Ilipa antiqua. De la prehistoria a la época romana: 69-92. Alcalá del Río.
FERNÁNDEZ UGALDE, A. y MARTÍN, A. (2006): "Excavación y extracción de una tumba romana a las afuera de Écija", Astigi Vetus 2: 111-124, Écija.

FERRER ALBELDA, E. (2006): "La Bahía de Cádiz en el contexto del mundo púnico. Aspectos étnicos y políticos", Spal 15: 267-280. http://dx.doi. org/10.12795/spal.2006.i15.14

- (2010): "La necrópolis fenicio-púnica de Gadir. Reflexiones a partir de un discurso identitario no esencialista", en A.M. Niveau de Villedary y V. Gómez (coords.), Las necrópolis de Cádiz. Apuntes de arqueología gaditana en homenaje a J.F. Sibón Olano: 69-91. Cádiz.

FERRER ALBELDA, E. y ÁLVAREZ, M. (2009): "Comunidad cívica e identidad étnica en la Iberia púnica", en F. Wulff y M. Álvarez (eds.), Identidades, culturas y territorios en la Andalucía prerromana: 205-235. Sevilla.

GARCÍA MATAMALA, B. y LIÉBANA, J.L. (2006): "Inhumaciones infantiles de tradición indígena en un sector de la necrópolis oriental de Corduba", en D. Vaquerizo, J.A. Garriguet y A. León (eds.), Espacio y usos funerarios en la ciudad histórica. $A A C$ 17, Vol. I: 99-114. Córdoba.

GARCÍA-BELLIDO, M.P. y BLÁZQUEZ, C. (2001): Diccionario de cecas y pueblos hispánicos. Vol. I: Introducción a la Numismática antigua de la Península Ibérica; Vol. II: Catálogo de cecas y pueblos que acuñan moneda. CSIC, Madrid.

GENER, J.M. (1999): "Seguimiento arqueológico en la obra de alcantarillado en la calle Santa Cruz de Tenerife y Avda. de Andalucía (Cádiz)", AAA'1994, Vol. III: 16-20.

GÓMEZ FERNÁNDEZ, V. (2007): Una aproximación al estudio de la necrópolis del Gades Altoimperial. Trabajo de Investigación inédito, Cádiz.

GÓMEZ FERNÁNDEZ, V. y SIBÓN, F.J. (2010): “La necrópolis altoimperial. Nuevos datos a partir de los resultados de la excavación arqueológica realizada en la Avenida de Andalucía, 35 (Cádiz), en A.M. Niveau de VIlledary y V-. Gómez (coords.), Las necrópolis de Cádiz. Apuntes de arqueología gaditana en homenaje a J.F. Sibón Olano: 387-405. Cádiz.

GÓMEZ SAUCEDO, M.T. (2001), "Excavaciones arqueológicas en la calle San Juan Grande $\mathrm{n}^{\circ} 2$ de Carmona (Sevilla)", AAA'1998, Vol. III.2: 871-882.

GOZALBES CRAVIOTO, C. (2006), "Documentos epigráficos acerca de las relaciones entre Hispania y Mauritania Tingitana", L'Africa romana XVI: 1337-1350. Roma. 
GUERRERO, S. y JUÁREZ, J.M. (1990): "Resumen de la memoria de las excavaciones arqueológicas efectuadas en Lora de Estepa (Sevilla) durante 1988”, AAA'1988, Vol. III: 315-322.

GUZMÁN, F.J. (2008): "Vestigios materiales de lo funerario en el Gades romano", F.J. Guzmán y V. Castañeda (coords.), Vida y Muerte en la Historia de Cádiz: 85-102. Chiclana de la Frontera.

HEINZELMANN, M. (2000): Die Nekropolen von Ostia. Untersuchungen zu den Gräberstrassen von der Porta Romana un dan der Via Laurentina. München.

JIMÉNEZ DÍEZ, A. (2005): Imagines Hibridae. Una aproximación postcolonialista al estudio de las necrópolis de la Bética y al debate sobre la "Romanización". Tesis Doctoral inédita, Universidad Autónoma de Madrid.

- (2006): "Culto a los ancestros en época romana: los cipos funerarios de las necrópolis de Baelo Claudia (Bolonia, Cádiz)", AEspA 80: 75-106.

- (2008): Imagines Hibridae. Una aproximación postcolonialista al estudio de las necrópolis de la Bética, Anejos de AEspA XLIII, Madrid.

JULIÁ, D. (1965) : “Les monuments funéraires en forme de demi-cylindre dans la province romaine de Tarragonaise", $M C V$ I : 29-54.

KOCKEL, V. (1987): "Im Tode gleich?. Die sullanischen Kolonisten und ihr kulturelles Gewicht in Pompeji am Beispiel der Nekropolen", em H. von Hesberg y P. ZANKER (eds.), Römische Gräberstrassen. Selbstdarstellung - Status - Standard: 183-198, Taf. 29-30. München.

LACAM, J.-C. (2009): «Le sacrifice du chien dans les communautés grecques, étrusques, italiques et romaines : approche comparatiste», MEFRA 120/12008: 29-80. Rome.

LÓPEZ DE LA ORDEN, M. D. (1997): «Dos nuevas inscripciones funerarias de la necrópolis romana gaditana», Gades 22. Homenaje al profesor José Luis Millán Chivite: 255-258. Cádiz.

LÓPEZ DE LA ORDEN, M.D. y RUIZ CASTELLANOS, A. (1995): Nuevas inscripciones latinas del Museo de Cádiz. Cádiz.

LÓPEZ ROSENDO, E. (2010): "Urnas pintadas de tradición prerromana en la necrópolis de Cádiz”, en A.M. Niveau de Villedary y V. Gómez (coords.), Las necrópolis de Cádiz. Apuntes de arqueología gaditana en homenaje a J.F. Sibón Olano: 145-177. Cádiz.

MACÍAS LÓPEZ, M.M. (2009): “Contribución de la Antropología y la Paleopatología a la interpretación en la Arqueología Funeraria. Un ejemplo en la necrópolis gaditana del siglo II a.C.", Anales de Arqueología Cordobesa 20: 67-94.

MARTÍN RIPOLL, P. y MARTÍNEZ PEÑARROYA, J. (1995): "Memoria de la actuación realizada en la Zona de Interés Arqueológico de Orippo", Polígono Industrial "Carretera de la Isla": (Dos Hermanas, Sevilla). Fase II, 1992”, AAA'1992, Volumen III: 685-694, Sevilla.

MARTÍN RUIZ, J.A. y PÉREZ-MALUMBRES, A. (1999): "La necrópolis de época tardo-púnica de los Campos Elíseos (Gibralfaro, Málaga)”, Madrider Mitteilungen 40: 146-159.

- (2001): "La necrópolis de Campos Elíseos (Gibralfaro, Málaga)", Actas del II Congreso de Historia Antigua de Málaga. Comercio y comerciantes en la Málaga antigua (siglo VIII a.C.-año 711 d.C.): 299326. Málaga.

MIRANDA, J.L. et alii (2001-2002): "Usos del suelo en la necrópolis de Cádiz: el proceso de distribución del espacio extramuros de la ciudad", en A. Gonzalez Blanco, G. Matilla y A. Egea (eds.), El mundo púnico. Religión, antropología y cultura material. Estudios Orientales 5-6: 243-265. Murcia.

MORALES, C. M. (2006): "La necrópolis de Gades: la complejidad de su ubicación", en AAVV, "Dossier: Arqueología de la Muerte", Revista De Historia Ubi sunt? 20: 32-41. Cádiz.

MOSCATI, S. (1988): "Le stele" en S. Moscati (dir.), I Fenici: 304-327. Venezia.

- (1995): Luci sul Meditarraneo: dai manoscritti del Mar Morto ai Cartaginesi in Italia, tre milenni di vicenze storiche, di conessioni religiose, di creazione artistiche alla luce dell'archeologia. Roma, 2 vols.

MUÑOZ VICENTE, Á. (2008): “Topografía y ritual de la necrópolis fenicio-púnica de Cádiz”, en F.J. Guzmán y V. Castañeda (coords.), Vida y Muerte en la Historia de Cádiz: 57-84. Chiclana de la Frontera.

NIVEAU DE VILLEDARY, A.M. (2008): "Compañero en la muerte o guía hacia el más allá? El perro en la liturgia funeraria púnica”, en E. Ferrer, J. Mazuelos y J.L. Escacena (coords.), De dioses y bestias. Animales y Religión en el mundo antiguo. Spal Monografias XI: 97-141. Sevilla.

- (2010): Ofrendas, banquetes y libaciones. El ritual funerario en la necrópolis púnica de Cádiz. Spal Monografias XII. Sevilla.

NIVEAU DE VILLEDARY, A.M. y FERRER, E. (2004): "Sacrificios de cánidos en la necrópolis púnica de Cádiz", en J. Fernández Jurado, C. García y P. Rufete (coords.), Actas del III Congreso 
Español de Antiguo Oriente Próximo. Huelva Arqueológica 20: 63-88. Huelva.

NIVEAU DE VILLEDARY, A.M. y GÓMEZ, V. (coords.) (2010a): Las necrópolis de Cádiz. Apuntes de arqueología gaditana en homenaje a J.F. Sibón Solano. Cádiz.

NIVEAU DE VILLEDARY,A.M. y GÓMEZ, V. (2010b): "Captación del agua en contextos funerarios y rituales. Estructuras hidráulicas en la necrópolis de Cádiz (siglos III a.C.-I d.C.)”, en L.G. Lagóstena, J.L. Cañizar y L. Pons (eds.), Aquam peducendam curavit. Captación, uso y administración del agua en las ciudades de la Bética y el Occidente romano: 511-532. Cádiz.

NOGUERA, J.M. y RODRÍGUEZ OLIVA, P. (2008): "Scultura ispànica in epoca repubblicana: note su generi, iconografia, usi e cronologia", en J. Uroz, J.M. Noguera y F. Coarelli (eds.), Iberia e Italia: modelos romanos de integración territorial: 379454. Murcia.

OLMOS, R. (1998): “Indigenismo y Romanización en la imagen ibérica de época republicana", en J. Mangas (ed.), Italia e Hispania en la crisis de la República Romana. Actas del III Congreso Histórico-Arqueológico Hispano-Italiano: 433-440. Madrid.

ORTALLI, J. (2001): "Il culto funerario della Cispadana romana. Rappresentazione e interiorità", en M. Heinzelmann et alii (eds.), Culto dei morti e costumi funerari romani. Roma, Italia settentrionale e province nord-occidentali dalla tarda Repubblica all'età imperiale, Internationales Kolloquium, Rom 1.-3. April 1998: 215-242. Deutsches Archäologisches Institut Rom, Wiesbaden.

PACHÓN, J.A. y RUIZ, J.I. (2006): Las Cuevas de Osuna. Estudio histórico-arqueológico de una necrópolis ruprestre de la Antigüedad. Osuna.

PARIS, P. et alii (1926), Fouilles de Belo (Bolonia, province de Cadix) (1917-1921). Tome II: La nécropole. Bibliothèque de l'École des Hautes Études Hispaniques VI, Paris.

PÉREZ LÓPEZ, I. (1999): Leones romanos en Hispania. Madrid.

QUINTERO ATAURI, P. (1932): Excavaciones de Cádiz: memoria de las excavaciones practicadas en 1929-1931. Madrid.

REMESAL, J. (1979): La Necrópolis Sureste de Baelo. EAE 104. Madrid.

RODÁ, I. (1989): "Consideracions sobre Bàrcino a propòsit dels seus monuments epigràfics", en Història urbana del Pla de Barcelona, Vol. II: 97-106. Barcelona.

RODERO, A. et alii (1996): «La necrópolis de Villaricos (Almería)», en M.A. Querol y T. Chapa,
Homenaje al Profesor Manuel Fernández Miranda, Complutum Extra 6-I, vol. I: 373-384.

RODRÍGUEZ GUTIÉRREZ, O. y RODRÍGUEZ, A. (2003): "Nuevos datos en torno al mundo funerario en la Sevilla romana: la necrópolis de cremación de la Puerta del Osario", Romula 2: 149-182.

RODRÍGUEZ OLIVA, P. (1996): "Las primeras manifestaciones de la escultura romana en la Hispania Meridional", a J. Massó y P. Sada (eds.), II Reunión sobre escultura romana en Hispania: 13-30. Tarragona.

- (2002): "Talleres locales de urnas cinerarias y de sarcófagos en la prouincia Hispania Ulterior Baetica", en D. Vaquerizo (ed.), Espacio y usos funerarios en el Occidente romano, Vol. I: 259-312. Córdoba.

ROMÁN RODRÍGUEZ, J.M. (2001): "El almacenamiento de grano en Carmona: el horreum de San Blas", en A. Caballos (ed.), Carmona Romana: 233-250. Carmona.

ROMÁN RODRÍGUEZ, J.M. y CONLIN, E. (2005): Nuevas aportaciones al poblado calcolítico de Carmona (Sevilla): excavaciones en la calle Calatrava no 4", $A A A$ '2002, Vol. III.2: 326-343.

ROMÁN RODRÍGUEZ, J.M. y VÁZQUEZ, J. (2005a): "Intervención Arqueológica de Urgencia en el solar $\mathrm{n}^{\mathrm{O}} 2$ de la calle Calatrava de Carmona (Sevilla)", $A A A^{\prime}$ '2002, vol. III.2: 344-362.

- (2005b): "Nuevas estructuras romanas de carácter monumental en Carmo: I.A.U. en el solar $\mathrm{n}^{\circ} 20$ de la C/ Hermanas de la Cruz de Carmona (Sevilla)", $A A A^{\prime} 2002$, vol. III.2: 369-393.

ROMERO DE TORRES, E. (1934): Catálogo Monumental de España. Provincia de Cádiz (1908-1909). Madrid, 2 vols.

ROSSIGNOLI, C. (1992): "Persistenza del culto betilico nell'Africa romana: Un'inscrizione da Thala (Tunisia)", en R. MASTINO (ed.), L'Africa Romana. Atti del IX convegno di studio su l'Africa romana, vol. 1: 73-96, Tav. I-VI. Sassari.

RUIZ GÁLVEZ, M. (Ed.) (1995): Ritos de paso y puntos de paso. La Ría de Huelva en el mundo del Bronce Final Europeo. Complutum, Extra $\mathrm{n}^{\mathrm{o}} 5$. Univ. Complutense de Madrid.

RUIZ OSUNA, A. B. (2010): Colonia Patricia, centro difusor de modelos. Topografia y monumentalización funeraria en Baetica. Arqueología Cordobesa 17. Córdoba.

SALZA PRINA, E. (2004): "I giardini delle tombe e quello della tomba di Antinoo", Rendiconti. Atti della Pontificia Accademia Romana di Arqueologia LXXVI. 2003-2004: 231-261. Roma. 
SCHATTNER, Th. (2003): Munigua. Cuarenta años de Investigaciones. Sevilla.

SECO, I. (2002): Piedras con alma. El betilismo en el mundo antiguo y sus manifestaciones en la Península Ibérica. Tesis Doctoral inédita, Universidad Autónoma de Madrid.

- (2010): Piedras con alma. El betilismo en el mundo antiguo y sus manifestaciones en la Península Ibérica. Spal Monografías XIII. Sevilla.

SIBÓN, F.; GÓMEZ, V. y NIVEAU DE VILLEDARY, A.M. (2007): "Intervención Arqueológica de Urgencia en el solar de la futura 'Ciudad de la Justicia' (Cádiz)”, Anuario Arqueológico Andaluz, Sevilla [en prensa].

STEINGRÄBER, S. (1991): "Etruskische Monumentalcippi", Archeologia Classica XLIII.2: 10791102.

TAGLIETTI, F. (2001): "Ancora su incinerazione e inumazione: la necropoli dell'Isola Sacra”, en M. Heinzelmann et alii (eds.), Culto dei morti e costumi funerari romani. Roma, Italia settentrionale e province nord-occidentali dalla tarda Repubblica all'età imperiale, Internationales Kolloquium, Rom 1.-3. April 1998:149-158. Deutsches Archäologisches Institut Rom, Wiesbaden.

TORE, G. (1975): "Su alcune stele funerarie sarde di età punico-romana", Latomus 34: 293-318.

TUPMANN, Ch. (2005): "The cupae of Iberia in their monumental contexts: a study of the relationship between social status and commemoration with barrel shaped and semi-cylindrical tombstones", J. Bruhn, B. Croxford y D. Grigoropoulos (eds.), TRAC 2004. Proceedings of the Fourteenth Annual Theoretical Roman Archaeology Conference: 119-132. Oxford.

VAQUERIZO, D. (2001): "Formas arquitectónicas funerarias, de carácter monumental en Colonia Patricia Corduba", AEspA 74: 131-160.
- (2002): "Espacio y usos funerarios en Corduba", en D. Vaquerizo (ed.), Espacio y usos funerarios en el Occidente Romano, Vol. II: 141-200. Córdoba.

- (2006): "Sobre la tradición púnica, o los influjos norteafricanos, en algunas manifestaciones arqueológicas del mundo funerario hispano-bético de época pleno-imperial. Una revisión crítica”, en D. Vaquerizo y J.F. Murillo (eds.), El concepto de lo provincial en el mundo antiguo. Homenaje a la Profra. Pilar León Alonso, Vol. II: 317-364. Córdoba.

- (2007): "Crematio et humatio in Hispania: cordubensis mos (2. Jahrhundert v. Chr. bis zum 2. Jahrhundert n. Chr.)“, en Körpergräber des 1.-3. Jahrhunderts in der römischen welt: 271-290. Frankfurt.

- (2008a): "Figurative imagery of the deceased in the Eastern Necropolis of Baelo Claudia", a E. La Rocca y P. León (eds.), Le due patrie acquisite. Studi di Archeologia dedicati a W. Trillmich, BullCom: 419-434. Roma.

- (2008b): "Topografía y usos funerarios en la capital de Baetica", Archaeologia Classica LIX: 63-111.

- (2010a): Necrópolis urbanas en Baetica. Tarragona.

- (2010b): "Espacio y usos funerarios en el Gades romano: ¿un lujo sacrificable...?”, en A. M. Niveau de Villedary y V. Gómez (coords.), Las necrópolis de Cádiz. Apuntes de arqueología gaditana en homenaje a J.F. Sibón Olano: 341-385. Cádiz.

VIDAL, N. de la O. y CAMPOS, J.M. (2006): "Las necrópolis de Onuba", en D. Vaquerizo, J.A. Garriguet y A. León (eds.), Espacio y usos funerarios en la ciudad histórica. AAC 17, Vol. I: 13-34. Córdoba.

ZAMPIERI, G. (2000): Claudia Toreuma Giocolera e Mima. Il monumento funerario. L'Erma, Roma.

ZANKER, P. (2002): "Discorsi presso la tomba. Le immagini dei sarcofagi mitologici: un linguaggio al superlativo", en D. Vaquerizo (ed.), Espacio y usos funerarios en el Occidente Romano, Vol. I: 51-66. Córdoba. 